\title{
Overview of the synoptic and pollution situation over Europe during the EUCAARI-LONGREX field campaign
}

\author{
T. Hamburger ${ }^{1}$, G. McMeeking ${ }^{2}$, A. Minikin ${ }^{1}$, W. Birmili ${ }^{3}$, M. Dall'Osto ${ }^{4}$, C. O'Dowd ${ }^{4}$, H. Flentje ${ }^{5}$, B. Henzing ${ }^{6}$,

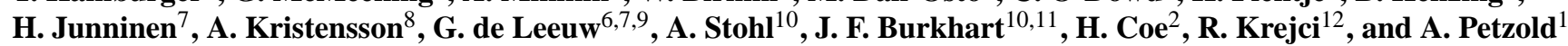 \\ ${ }^{1}$ Deutsches Zentrum für Luft- und Raumfahrt (DLR), Institut für Physik der Atmosphäre, Oberpfaffenhofen, \\ 82234 Wessling, Germany \\ ${ }^{2}$ School of Earth, Atmospheric and Environmental Sciences, University of Manchester, Manchester M13 9PL, UK \\ ${ }^{3}$ Leibniz-Institut für Troposphärenforschung, 04318 Leipzig, Germany \\ ${ }^{4}$ School of Physics and Centre for Climate and Air Pollution Studies (C-CAPS), Environmental Change Institute (ECI), \\ National University of Ireland, Galway, Ireland \\ ${ }^{5}$ Hohenpeissenberg Meteorological Observatory, German Meteorological Service, 82383 Hohenpeissenberg, Germany \\ ${ }^{6}$ Unit Environment, Health and Safety, TNO, P.O. Box 80015, 3508 TA Utrecht, The Netherlands \\ ${ }^{7}$ Department of Physics, P.O. Box 64, 00014 University of Helsinki, Helsinki, Finland \\ ${ }^{8}$ Division of Nuclear Physics, Department of Physics, Lund University, P.O. Box 118, 22100 Lund, Sweden \\ ${ }^{9}$ Finnish Meteorological Institute, Climate Change Unit, P.O. Box 503, 00101 Helsinki, Finland \\ ${ }^{10}$ Norwegian Institute for Air Research (NILU), P.O. Box 100, 2027 Kjeller, Norway \\ ${ }^{11}$ School of Engineering, University of California Merced (UCM), 5200 North Lake Rd., Merced, CA 95343, USA \\ ${ }^{12}$ Department of Applied Environmental Science (ITM), Stockholm University, 10691 Stockholm, Sweden
}

Received: 2 July 2010 - Published in Atmos. Chem. Phys. Discuss.: 13 August 2010

Revised: 19 January 2011 - Accepted: 21 January 2011 - Published: 7 February 2011

\begin{abstract}
In May 2008 the EUCAARI-LONGREX aircraft field campaign was conducted within the EUCAARI intensive observational period. The campaign aimed at studying the distribution and evolution of air mass properties on a continental scale. Airborne aerosol and trace gas measurements were performed aboard the German DLR Falcon 20 and the British FAAM BAe-146 aircraft. This paper outlines the meteorological situation over Europe during May 2008 and the temporal and spatial evolution of predominantly anthropogenic particulate pollution inside the boundary layer and the free troposphere. Time series data of six selected ground stations are used to discuss continuous measurements besides the single flights. The observations encompass total and accumulation mode particle number concentration $(0.1-0.8 \mu \mathrm{m})$ and black carbon mass concentration as well as several meteorological parameters. Vertical profiles of total aerosol number concentration up to $10 \mathrm{~km}$ are compared to vertical profiles probed during previous studies.
\end{abstract}

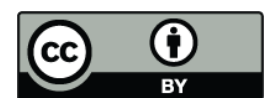

Correspondence to: T. Hamburger (thomas.hamburger@dlr.de)
During the first half of May 2008 an anticyclonic blocking event dominated the weather over Central Europe. It led to increased pollutant concentrations within the centre of the high pressure inside the boundary layer. Due to long-range transport the accumulated pollution was partly advected towards Western and Northern Europe. The measured aerosol number concentrations over Central Europe showed in the boundary layer high values up to $14000 \mathrm{~cm}^{-3}$ for particles in diameter larger $10 \mathrm{~nm}$ and $2300 \mathrm{~cm}^{-3}$ for accumulation mode particles during the high pressure period, whereas the middle free troposphere showed rather low concentrations of particulates. Thus a strong negative gradient of aerosol concentrations between the well mixed boundary layer and the clean middle troposphere occurred.

\section{Introduction}

The European integrated project on Aerosol Cloud Climate and Air Quality Interactions (EUCAARI) project focuses on understanding the interactions of climate and air pollution (Kulmala et al., 2009). As part of the EUCAARI intensive observational period, an aircraft field campaign (EUCAARI-LONGREX, where LONGREX stands for long

Published by Copernicus Publications on behalf of the European Geosciences Union. 
range experiment) was conducted in May 2008. This paper presents an overview of the meteorological conditions (Sect. 3) combined with a survey of the temporal evolution and spatial distribution of anthropogenic particulate pollution over Europe during this aircraft campaign (Sect. 5). Accompanying papers discuss specific aerosol aspects that were observed under these meteorological conditions including the aerosol chemical composition and evolution of the organic fraction (Morgan et al., 2010), black carbon measurements (McMeeking et al., 2010) and atmospheric sub-3 nm particles at high altitudes (Mirme et al., 2010). Aerosol microphysical properties will be discussed in a forthcoming paper. This study provides the meteorological framework necessary to discuss the aerosol observations during the EUCAARILONGREX campaign and puts the measurements into a synoptic and climatological context

The EUCAARI-LONGREX campaign focuses on airborne in-situ and remote sensing measurements on a rather large horizontal scale in the whole tropospheric column using two aircraft in May 2008, DLR Falcon 20 and FAAM BAe-146. The aircraft campaign aimed for the following objectives: mapping of tropospheric aerosol over Europe, observation of gradients in aerosol properties from clean to polluted air masses and the transitions between industrial dominated and agricultural dominated regions, air mass evolution and transformation during long-range transport, and linking of airborne to ground based measurements by intensive profiling over EUSAAR (European Supersites for Atmospheric Aerosol Research) super-sites.

The comparison of airborne and ground based measurements helps to asses the representativeness of airborne measurements within the temporal evolution of aerosol properties and the representativeness of ground based measurements within the spatial aerosol distribution. Six EUSAAR supersites were selected for the present analysis to provide continuous measurements of atmospheric properties over Europe in May 2008.

Atmospheric conditions govern the lifecycle of aerosol microphysical phenomena by uptake of primary particles and aerosol precursors, providing favourable conditions for new particle formation and transformation processes during transport, and removal of particulate matter from the atmosphere (Raes et al., 2000). Several long term studies investigated the impact of meteorological conditions and different air mass transport paths on local aerosol properties at ground based measurement sites (e.g., Birmili et al., 2001; Tunved et al., 2005).

The accumulation mode is the dominant mode in the region of central European cities (Berner et al., 2004) and high accumulation mode particle concentrations at rural locations indicate long-range transport of polluted continental air masses (Tunved et al., 2005). Accumulation mode particles also play an important role in governing the optical properties inside the continental boundary layer. Robles González et al. (2003) showed that large aerosol optical depth over con- tinental Central Europe results from a high particle load in the accumulation mode. One reason is the hygroscopicity of continental and urban aerosol in the accumulation mode size range (Kandler and Schütz, 2007) and the resulting effect on the visibility with growing particles at higher relative humidity. Increased BC-mass concentrations at rural background stations also indicate anthropogenic influences on the air masses by combustion of fossil fuel or biomass burning (Van Dingenen et al., 2004). Accumulation mode particle and BC-mass concentrations are examined for the six ground stations. Aerosol total number concentrations, which are usually dominated by particles present in the Atiken mode (below $0.1 \mu \mathrm{m}$ particle diameter), will be used for the comparison of an extensive set of vertical profiles over Southern Germany and local ground based condensation nuclei $(C N)$ time series.

\section{Measurements and analysis methods}

The research flights were performed with the FAAM BAe146 and the DLR Falcon 20 aircraft. Both aircraft operated from Oberpfaffenhofen $\left(48.08^{\circ} \mathrm{N}, 11.28^{\circ} \mathrm{E}\right)$, Germany. Most flights were performed as coordinated research flights. The flights of the FAAM BAe-146 were mainly conducted in the boundary layer and lower free troposphere, whereas the flights of the DLR Falcon 20 focused on the free troposphere up to the tropopause level. Table 1 gives an overview of all flights performed within the EUCAARI-LONGREX campaign.

The ground sites selected to evaluate the temporal evolution of the pollution inside the boundary layer are composed of the EUSAAR sites at Hyytiälä $\left(61.85^{\circ} \mathrm{N}\right.$, $24.28^{\circ} \mathrm{E}, \quad 181 \mathrm{~m}$ a.s.1. $), \quad$ Vavihill $\left(56.02^{\circ} \mathrm{N}, \quad 13.15^{\circ} \mathrm{E}\right.$, $172 \mathrm{~m}$ a.s.1.), Mace $\operatorname{Head}\left(53.32^{\circ} \mathrm{N}, 9.88^{\circ} \mathrm{W}, 5 \mathrm{~m}\right.$ a.s.1.), Cabauw $\left(51.97^{\circ} \mathrm{N}, 4.93^{\circ} \mathrm{E}, 60 \mathrm{~m}\right.$ a.s.l.), Melpitz $\left(51.53^{\circ} \mathrm{N}\right.$, $12.90^{\circ} \mathrm{E}, 87 \mathrm{~m}$ a.s.1.), and Hohenpeißenberg $\left(47.80^{\circ} \mathrm{N}\right.$, $11.01^{\circ} \mathrm{E}, 977 \mathrm{~m}$ a.s.l.) (Fig. 1). The accumulation mode number concentrations in the size range between $0.1-0.8 \mu \mathrm{m}$ were retrieved from aerosol size distributions measured by Differential (DMPS) or Scanning Mobility Particle Spectrometer (SMPS) (Wang and Flagan, 1990) at the ground stations and Passive Cavity Aerosol Spectrometer Probes (PCASP) Model 100 (Liu et al., 1992) operated aboard the aircraft. BC mass concentrations were determined at the ground stations using the Multi Angle Absorption Photometer (MAAP) (Petzold and Schönlinner, 2004) and by a Single Particle Soot Photometer (SP2) (Stephens et al., 2003) operating on the FAAM BAe-146. A detailed analysis of airborne $\mathrm{BC}$ measurements during the EUCAARILONGREX campaign can be found in McMeeking et al. (2010). Condensation nuclei $(C N)$ number concentrations of particles with a diameter larger $10 \mathrm{~nm}$ were measured aboard the DLR Falcon 20 by a condensation particle size analyser (CPSA) (Stein et al., 2001). All concentrations in the present 


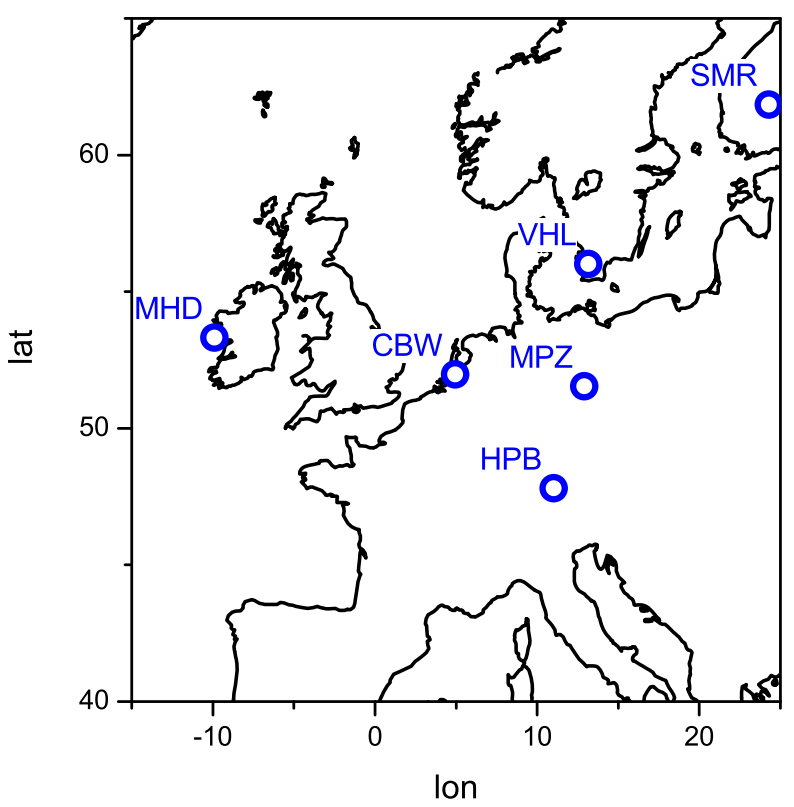

Fig. 1. EUSAAR ground stations. CBW: Cabauw, MHD: Mace Head, MPZ: Melpitz, SMR: Hyytiälä, VHL: Vavihill, HPB: Hohenpeißenberg.

analyses retrieved by airborne measurements are reported as concentrations at standard temperature $(T=273.15 \mathrm{~K})$ and pressure $(p=1013.25 \mathrm{hPa})$.

The data used for the meteorological analysis were retrieved from the operational archive of the ECMWF. The model has a horizontal resolution of $0.225^{\circ} \times 0.225^{\circ}$ and a vertical resolution of 91 levels. Hess and Brezowsky Grosswetterlagen (GWL) (Hess and Brezowsky, 1952; Gerstengarbe and Werner, 2005), describing large-scale circulation patterns over Europe and the North-East Atlantic (James, 2007), are used to describe the general circulation over Europe. GWL data are provided by the German Weather Service DWD (http://www.dwd.de/GWL).

\section{The meteorological situation over Europe in May 2008}

The synoptic situation in May 2008 can be divided into two major periods with an approximate duration of two weeks each. The first half of May (1-15 May; hereafter period a) was dominated by an anticyclone blocking event, whereas the second half (16-31 May; hereafter period b) was dominated by westerly flow and passage of frontal systems over Central Europe. The following description of the synoptic situation focuses on the days during the EUCAARILONGREX campaign when measurement flights were performed with the FAAM BAe-146 and the DLR Falcon 20. Figure 2 shows the mean geopotential height at $850 \mathrm{hPa}$ and the integrated precipitation per flight day, calculated for a time span between 00:00-24:00 UTC of the respective day. The plots are overlaid by the flight tracks of the FAAM BAe146 and the DLR Falcon 20 aircraft. The GWL occurring in May 2008 are listed in Table 2.

Between the measurement flights on 6 May until 11 May dry and stable conditions could be observed over Central Europe caused by a high over Central Europe (Hoch Mitteleuropa: HM). The centre of the anticyclone remained approximately stationary over the North Sea and Denmark. Its maximum surface pressure values averaged at $1032 \mathrm{hPa}$ on 6 May. Horizontal wind speeds at $850 \mathrm{hPa}$ level in the core region of the anticyclone were quite low with $0-7 \mathrm{~m} / \mathrm{s}$ compared to its western, northern and eastern borders. Wind speeds increased up to $10-20 \mathrm{~m} / \mathrm{s}$ due to the higher pressure gradient along these borders, caused by surrounding cyclones. These surrounding cyclones also led to an intensification and maintenance of the $\Omega$ shaped anticyclone which can be described as a blocking event.

Subsiding air masses in the core region of the anticyclone caused almost clear sky conditions with only few clouds (mainly cu and strcu) occurring rarely on the top of the continental and marine boundary layer. Thick cloud cover and precipitation occurred over Southwest Europe and west of the British Isles associated with the frontal systems of the surrounding cyclones. In addition precipitation occurred on the west side of the Scandinavian Mountains induced by the eastward transport of moist marine air masses from the Norwegian Sea.

The anticyclone left its stationary position on 11 May and moved until 14 May westwards into the Atlantic north east of the British Isles and turned from an $\Omega$-blocking into a socalled split-flow block (Barriopedro et al., 2006). The general circulation pattern was identified as an Icelandic high with a ridge over Central Europe (Hoch Nordmeer-Island, antizyklonal: $\mathrm{HNa}$ ). The ridge associated with the high pressure reached from the British Isles towards Northern Germany and maintained stable synoptic conditions in this region. Cyclones moving from the Atlantic towards continental Europe via the Bay of Biscay south of the anticyclone led to a westward transport of air masses from Central Europe to the Atlantic. The anticyclone started to decay on 14 May.

A trough over Central Europe (Trog Mitteleuropa: TM) evolved on 16 May and lasted until 18 May. Frontal systems associated with the trough led to the first precipitation over the Benelux states and Germany since the first measurement flights had been performed. They changed the flow regime from westward to eastward air mass transport. Arctic air masses were now advected via the North Sea towards Northern Germany.

The flow regime changed again its wind direction over Central Europe beginning with 18 May with the onset of an anticyclonic North-Easterly pattern (Nordostlage, antizyklonal, NEa). Two cyclones formed consecutively over 

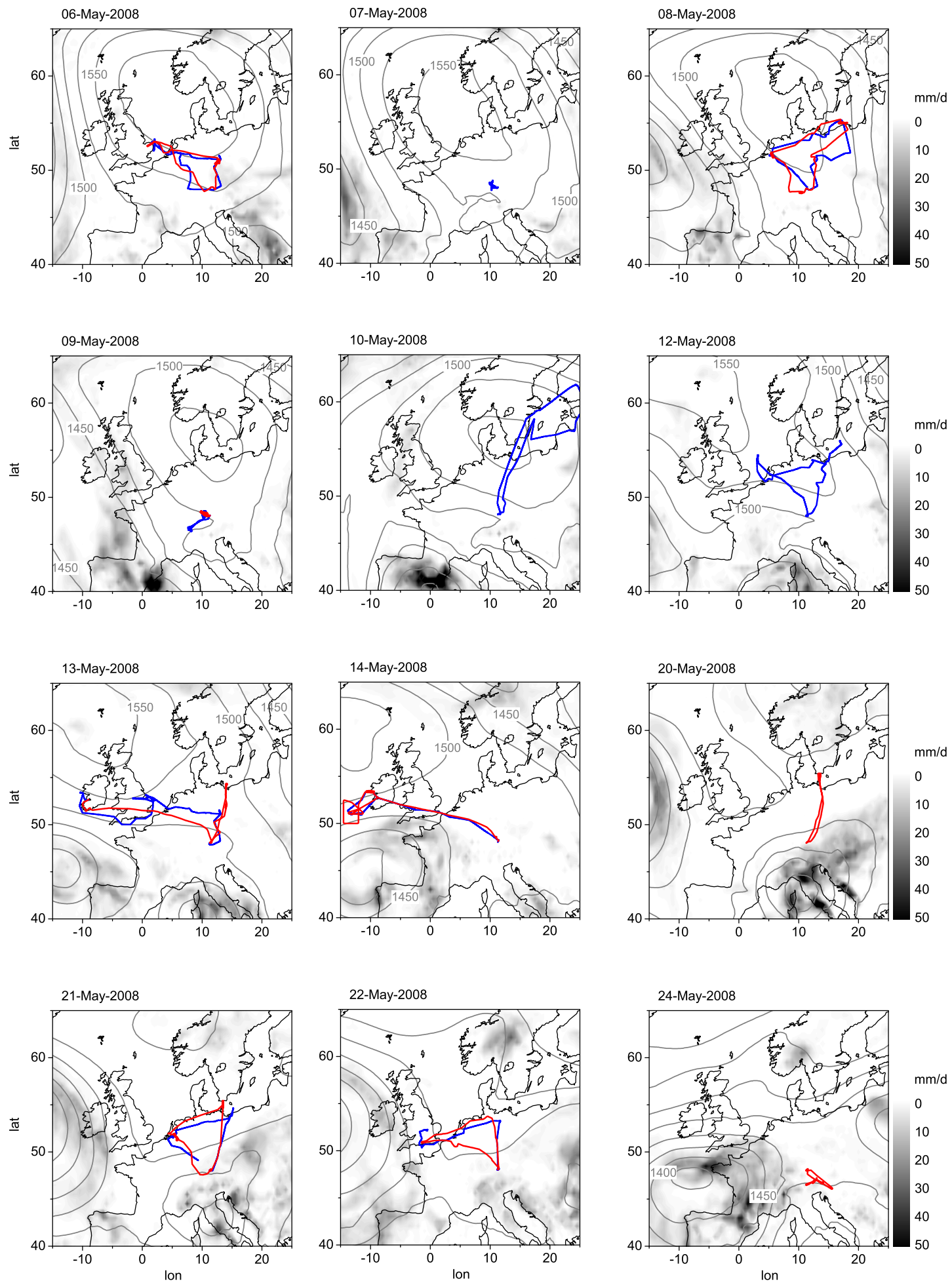

Fig. 2. FAAM BAe-146 (blue line) and DLR Falcon 20 (red line) flight tracks. Meteorological situation on the flight days showing mean geopotential height $(\mathrm{m})$ at $850 \mathrm{hPa}$ (solid gray line) and sum of daily precipitation $(\mathrm{mm} / \mathrm{d})$ (white to black shading). Mean and sum values are calculated for 00:00-24:00 UTC on the respective day. 
Table 1. Flight summary of DLR Falcon 20 and FAAM BAe-146 during the EUCAARI-LONGREX campaign containing take off time (T/O) and landing time (L) of the flights at local time (LT) and the median mean sea level pressure (MSLP) along each flight track. The MSLP was retrieved from the ECMWF operational archive.

\begin{tabular}{|c|c|c|c|c|c|c|c|c|}
\hline \multirow[b]{2}{*}{ Date } & \multicolumn{4}{|c|}{ DLR Falcon 20} & \multicolumn{4}{|c|}{ BAe-146 } \\
\hline & Flight ID & $\mathrm{T} / \mathrm{O}$ & $\mathrm{L}$ & MSLP & Flight ID & $\mathrm{T} / \mathrm{O}$ & $\mathrm{L}$ & MSLP \\
\hline \multirow[t]{2}{*}{6 May 2008} & 080506a & 09:36 & $12: 25$ & 1026 & b362 & 09:09 & $13: 51$ & 1026 \\
\hline & $080506 b$ & $15: 26$ & 18:00 & 1025 & b363 & $15: 13$ & $18: 25$ & 1025 \\
\hline 7 May 2008 & & & & & b364 & $13: 27$ & $15: 51$ & 1020 \\
\hline \multirow{2}{*}{8 May 2008} & $080508 \mathrm{a}$ & 08:08 & $11: 47$ & 1021 & b365 & $08: 24$ & $12: 30$ & 1020 \\
\hline & $080508 \mathrm{~b}$ & $13: 45$ & $17: 31$ & 1017 & b366 & $13: 54$ & $17: 09$ & 1017 \\
\hline 9 May 2008 & $080509 a$ & $11: 39$ & $15: 03$ & 1015 & b367 & $12: 22$ & $16: 50$ & 1015 \\
\hline \multirow[t]{2}{*}{10 May 2008} & & & & & b368 & 08:04 & $13: 00$ & 1022 \\
\hline & & & & & b369 & $14: 30$ & $18: 12$ & 1023 \\
\hline \multirow[t]{2}{*}{12 May 2008} & & & & & b370 & $06: 15$ & $12: 36$ & 1019 \\
\hline & & & & & b371 & $13: 51$ & $18: 04$ & 1019 \\
\hline \multirow[t]{2}{*}{13 May 2008} & $080513 a$ & $10: 41$ & $13: 55$ & 1017 & b372 & $08: 56$ & $13: 28$ & 1018 \\
\hline & $080513 b$ & $14: 56$ & $17: 43$ & 1016 & b373 & $14: 46$ & $18: 27$ & 1016 \\
\hline \multirow[t]{2}{*}{14 May 2008} & $080514 a$ & 09:16 & $12: 58$ & 1015 & b374 & $09: 41$ & $14: 39$ & 1015 \\
\hline & $080514 b$ & $14: 21$ & $16: 38$ & 1012 & b375 & $15: 54$ & $18: 18$ & 1012 \\
\hline 20 May 2008 & 080520a & $10: 25$ & $14: 02$ & 1017 & & & & \\
\hline \multirow[t]{2}{*}{21 May 2008} & $080521 \mathrm{a}$ & 07:59 & $11: 11$ & 1020 & b379 & 08:03 & $13: 27$ & 1018 \\
\hline & $080521 b$ & $12: 31$ & $15: 10$ & 1017 & & & & \\
\hline \multirow[t]{2}{*}{22 May 2008} & $080522 \mathrm{a}$ & $08: 55$ & $11: 55$ & 1015 & b380 & $08: 57$ & $13: 20$ & 1016 \\
\hline & $080522 b$ & $12: 44$ & $13: 44$ & 1015 & & & & \\
\hline 24 May 2008 & $080524 a$ & $06: 26$ & $10: 22$ & 1013 & & & & \\
\hline
\end{tabular}

Table 2. Grosswetterlagen (GWL) in May 2008 given by the DWD.

\begin{tabular}{lllc}
\hline GWL & Original definition (German) & Translated definition (English) & Date in 2008 \\
\hline TB & Tief Britische Inseln & Low over the British Isles & 28 Apr-2 May \\
HFa & Hoch Fennoskandien, antizyklonal & Scandinavian High, Ridge C. Europe & 3 May-6 May \\
HM & Hoch Mitteleuropa & High over Central Europe & 7 May-11 May \\
$\mathrm{HNa}$ & Hoch Nordmeer-Island, antizyklonal & Icelandic High, Ridge C. Europe & 12 May-14 May \\
$\mathrm{TrW}$ & Trog Mitteleuropa & Trough over Central Europe & 16 May-18 May \\
$\mathrm{NEa}$ & Nordostlage, antizyklonal & Anticyclonic North-Easterly & 19 May-24 May \\
$\mathrm{NEz}$ & Nordostlage, zyklonal & Cyclonic North-Easterly & 25 May-27 May \\
$\mathrm{SEz}$ & Südostlage, zyklonal & Cyclonic South-Easterly & 28 May-31 May \\
\hline
\end{tabular}

Northern Italy with a minimum sea level pressure of $997 \mathrm{hPa}$ on 20 May.

The horizontal wind speed of the easterly flow on the northern flanks of these cyclones was between $5-15 \mathrm{~m} / \mathrm{s}$ at $850 \mathrm{hPa}$ level over Central Europe.

The easterly flow merged with the northerly flow associated with a further cyclone located over Scandinavia. The cyclones located over Northern Italy advected warm and moist air masses from the Mediterranean via the Balkan Peninsula towards Central and Eastern Europe. In contrast, the cyclone located over Scandinavia advected cold air masses along the Norwegian Sea and the North Sea towards Central Europe. The front line of these two air masses extended from the
Alps, the Czech Republic, Southern Poland and Belarus to Russia, and caused thick cloud cover and precipitation. This front of air masses remained from 18 May until 22 May. Only few cumulus and stratocumulus clouds occurred in the cold air masses over land north of this front.

A ridge located over Italy and Germany caused quite fair weather over the Eastern part of the Alps in the morning of 24 May. Light convection formed some cumulus clouds during the day. 


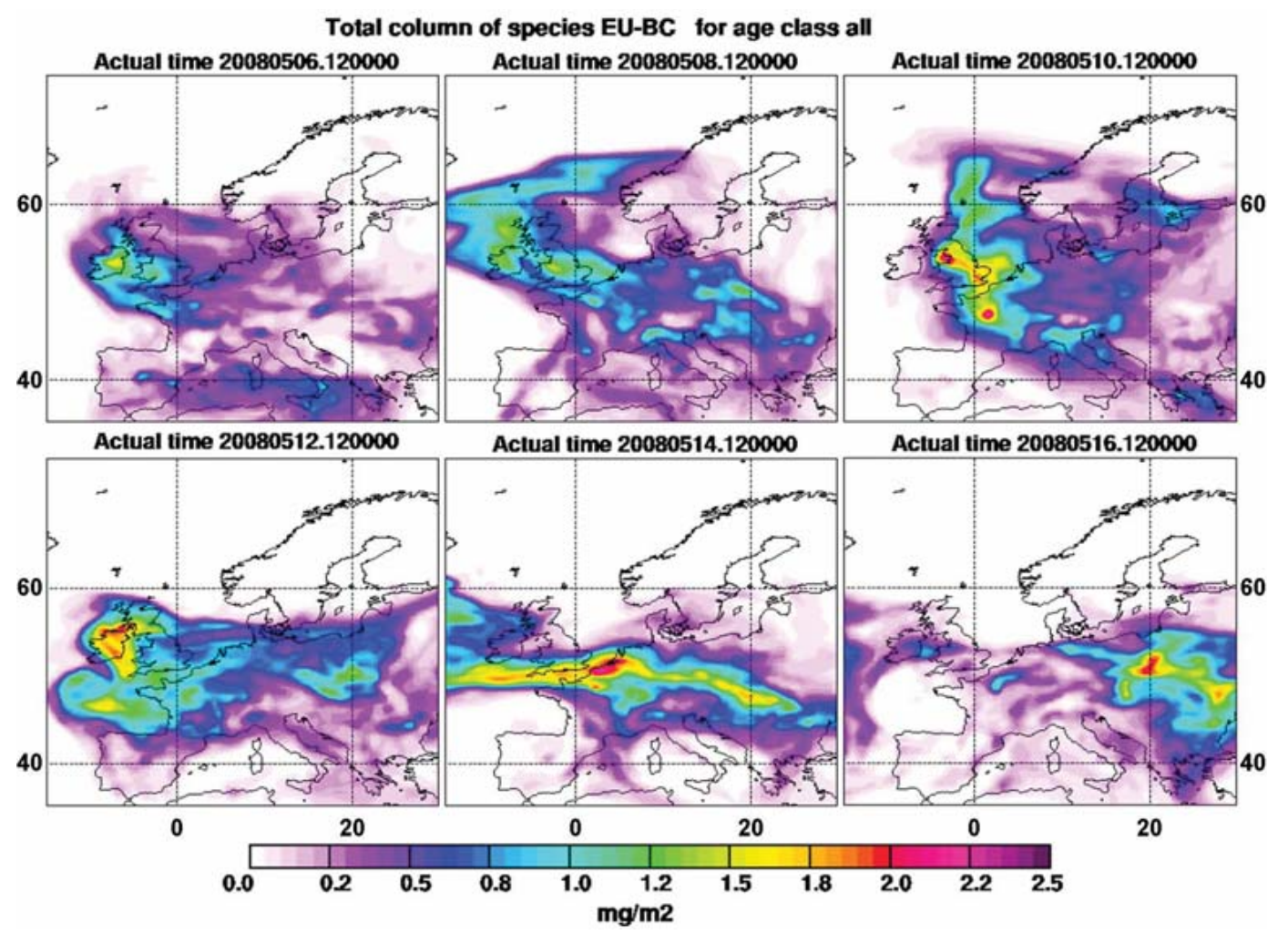

Fig. 3. BC column mass concentrations retrieved from FLEXPART analysis between 6 May 2008 and 16 May 2008.

\section{The synoptic situation within a climatological context}

Synoptic weather types over Central Europe have been classified into GWL since 1881 (Hess and Brezowsky, 1952), giving the possibility to place the synoptic situation encountered during EUCAARI-LONGREX into a climatological context. The overall number of large-scale circulation patterns ( $29 \mathrm{GWLs})$ is too large to reasonably study the statistics of frequency and duration per month or season of each single pattern, even though the data have been collected since more than one century (Gerstengarbe and Werner, 2005). Thus the patterns will be grouped into two categories for the present study and the statistics will be calculated for the months April, May and June between 1977-2007. The first group comprises the patterns representing high pressure over Europe and the second group all patterns leading to an anticyclonic flow pattern over Europe, including high pressure situations.

The first group contains amongst others the patterns HFa, HM and NEa which occurred during EUCAARI-LONGREX (see Table 2). The patterns HFa and HM were part of the blocking event and led to 9 consecutive days of high pressure over Europe. NEa formed during period (b) and lasted for 5 days. The median duration of consecutive patterns representing high pressure for the months April, May and June between 1977-2007 is 5.5 days, the 75th percentile 9 days. The sum of the duration of the two patterns HFa and HM in May 2008 equals 9 days. In average similar consecutive patterns with an overall duration of 9 days or more occur approximately once between April and June per year.

The second group contains the patterns mentioned above including $\mathrm{HNa}$, the third pattern which was part of the life cycle of the blocking event. It lasted for 3 days. Hence, the blocking event covered 12 consecutive days of anticyclonic flow pattern over Europe. This is twice as long as the median duration of 6 days for the period between April and June between 1977-2007 but less than the 75-th percentile of 13 days. Consecutive patterns inducing an anticyclonic flow over Europe and lasting 12 days or longer occur approximately twice between April and June per year.

\section{Temporal and spatial evolution of the pollution situation over Europe}

We describe the temporal evolution of pollution over Europe at selected EUSAAR ground sites in combination with the synoptic situations described in Sect. 3. Six sites were selected to cover both rural regions representative of background conditions and sites situated in highly polluted 
regions in Central Europe (Fig. 1). In addition the ground based measurements were combined with airborne aerosol measurements inside the boundary layer in the vicinity of the ground sites.

Figure 3 shows the horizontal distribution of columnintegrated $\mathrm{BC}$ mass concentrations from European anthropogenic emissions obtained from a simulation with the Lagrangian particle dispersion model FLEXPART (Stohl et al., 2005). The panels show $48 \mathrm{~h}$ intervals beginning with the high pressure over Central Europe on 6 May until the displacement of the anticyclone into the North-East Atlantic which occurred between 11 and 14 May. On 10 May the anthropogenic emissions were concentrated inside the boundaries of the anticyclone with its core situated over Denmark. Within this core region Central European pollution re-circulated via the North Sea and Southern Scandinavia back to Northern Germany. The polluted region reached a northward extension to approximately $65^{\circ} \mathrm{N}$ and shows a clear zonal gradient between $15^{\circ} \mathrm{W}-20^{\circ} \mathrm{E}$ with increasing concentrations from East to West due to the westward transport of continental air masses. With the displacement of the anticyclone the re-circulation of pollutants ceased and the polluted continental air masses were advected towards the British Isles and into the North-East Atlantic. After the anticyclone decayed, a trough over Western Europe formed on 16 May. Maximum concentrations of European anthropogenic BC occurred over Eastern Europe at this time indicating an eastward transport of pollutants. The northern border between clean Nordic and polluted Central European air masses appeared at approximately $55^{\circ} \mathrm{N}$ on this day.

\subsection{Meteorology and pollution measured at ground sites in May 2008}

Time series plots for ground stations are shown in Figs. 49. Each graph consists of four panels. The uppermost time series displays the number concentration of the accumulation mode particles. In addition airborne measurements of FAAM BAe-146 and DLR Falcon 20 are plotted in the graph, in cases where the aircraft were close to the EUSAAR sites. Only horizontal flight legs inside the boundary layer with a maximum distance of $150 \mathrm{~km}$ to the respective ground station were selected. Time series of BC measurements are shown in the second panel from the top. The original time resolution data are overlaid by a running average $(3 \mathrm{~h})$ to distinguish tendencies within highly variable time series like that observed during period (a) at Cabauw (Fig. 9). The third and fourth panels display the meteorological parameters temperature and wind direction and sea level pressure and precipitation, respectively.

Average values (median, 10-th and 90-th percentiles) of accumulation mode number concentrations and $\mathrm{BC}$ mass concentrations are presented in Table 3. The averaging time was split up into two periods, between 1 and 15 May

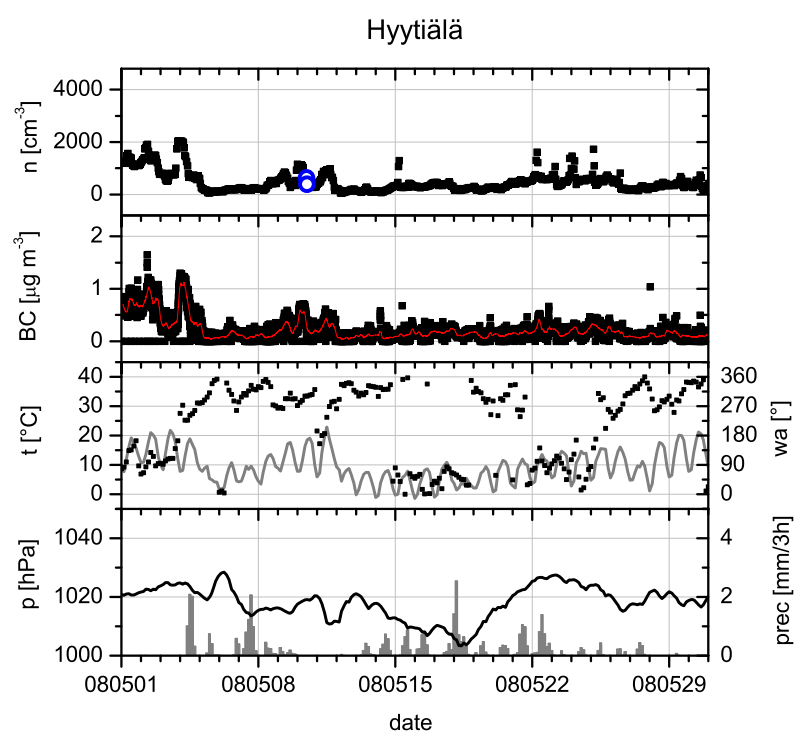

Fig. 4. Time series of accumulation mode number concentrations (AM) in the size range $0.1-0.8 \mu \mathrm{m}$ (particles $\left.\mathrm{cm}^{-3}\right)(1 \mathrm{st}$ panel, black squares), black carbon (BC) mass concentrations $\left(\mu \mathrm{g} \mathrm{m}^{-3}\right)$ (2nd subplot, black squares), temperature $\left({ }^{\circ} \mathrm{C}\right)$ (3rd subplot, grey line), wind direction $\left(^{\circ}\right)$ (3rd subplot, black squares), mean sea level pressure $(\mathrm{hPa})$ (4th subplot, black line), and precipitation $(\mathrm{mm} / 3 \mathrm{~h})$ (4th subplot, grey columns) for Hyytiälä. The AM number concentrations are overlaid by airborne measurements in the vicinity of the respective station inside the boundary layer. Blue circles denote measurements performed by the FAAM BAe-146, red circles measurements performed by the DLR Falcon 20. The BC mass concentrations are overlaid by an running average (red line).

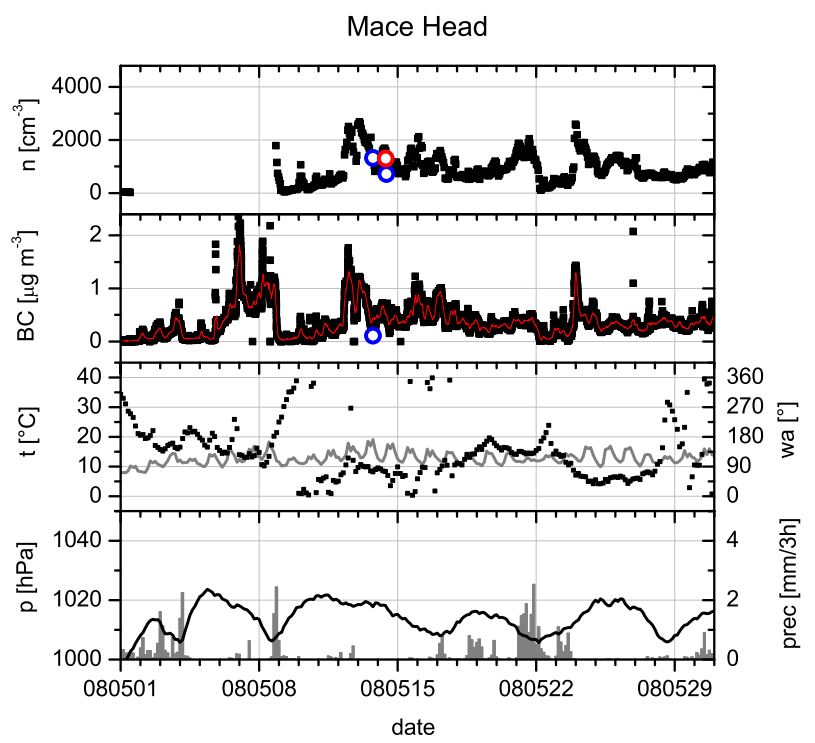

Fig. 5. Same as Fig. 4 for Mace Head. 


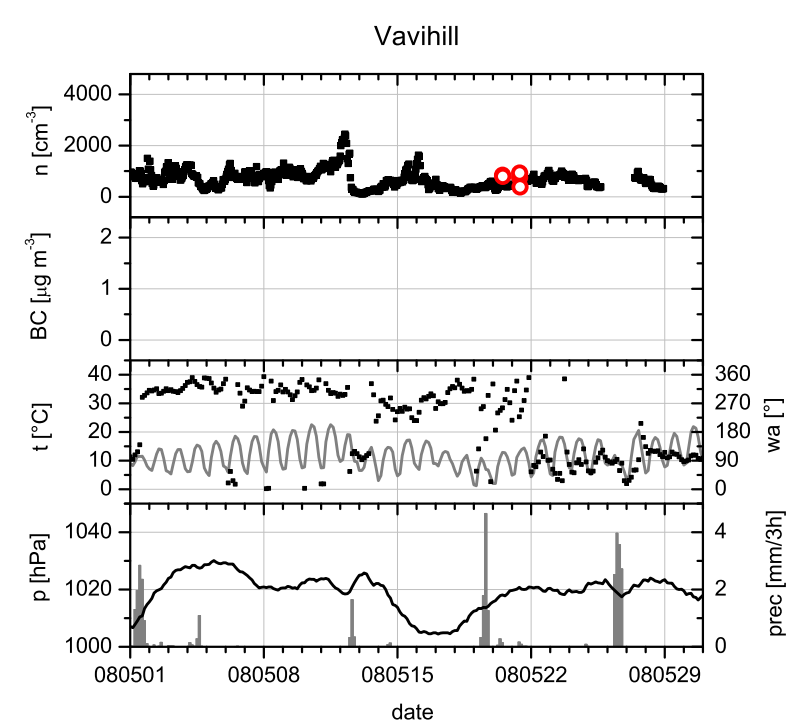

Fig. 6. Same as Fig. 4 for Vavihill.

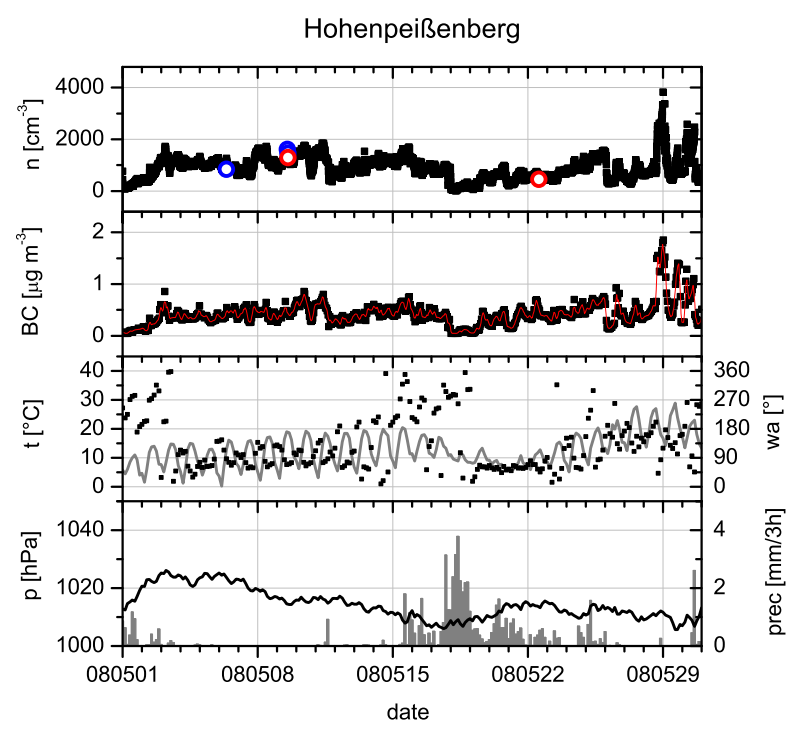

Fig. 7. Same as Fig. 4 for Hohenpeißenberg.

(period a) and between 16 and 31 May (period b). The two periods depict the time during and after the anticyclonic blocking event.

\subsubsection{Ground stations outside the high pressure core region}

\section{Hyytiälä and Mace Head}

Regarding the time series data in Figs. 4 and 5 the statistical values given in Table 3 the ground stations at Hyytiälä and

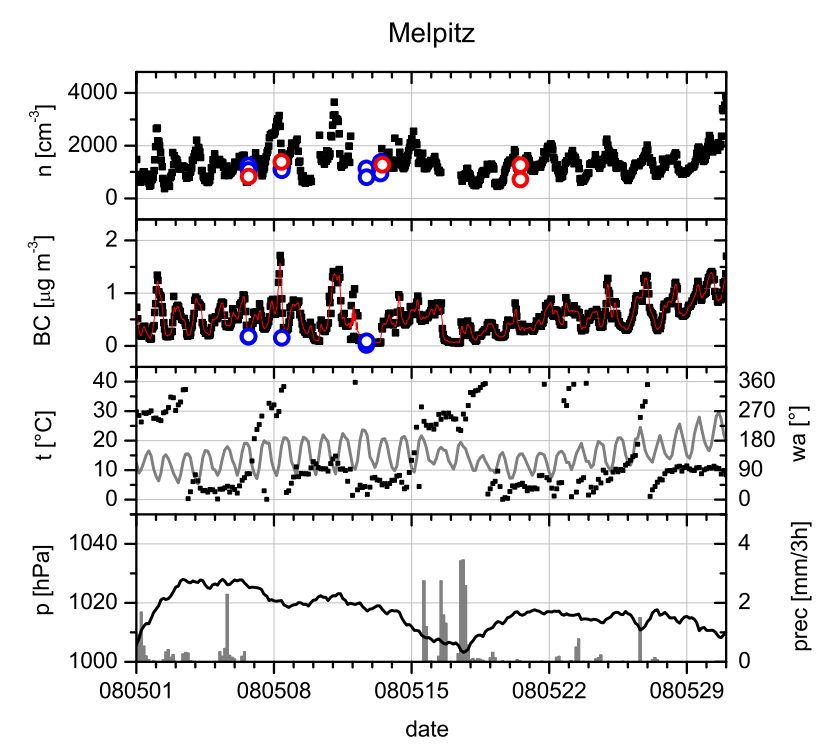

Fig. 8. Same as Fig. 4 for Melpitz.

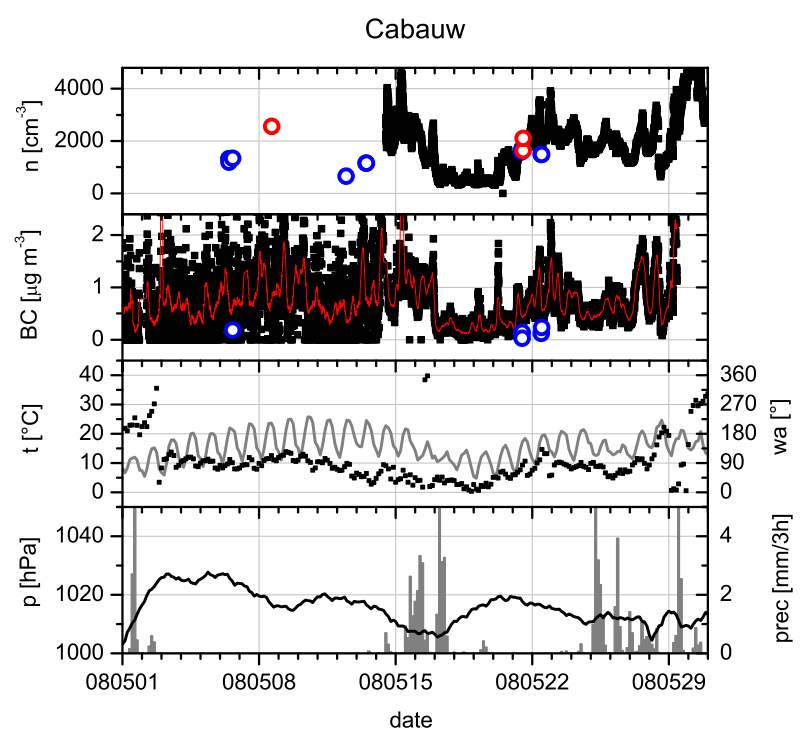

Fig. 9. Same as Fig. 4 for Cabauw.

Mace Head show no obvious coherence with the two distinctive synoptic situations during periods (a) and (b). The prevailing synoptic conditions at each station governed individual pollution events rather than the long term pollution trends during the blocking event.

The northernmost ground station at Hyytiälä shows highest accumulation mode particle number concentrations for wind directions between east, south and west. Peak values of individual events reached approximately 2000 accumulation mode particles $\mathrm{cm}^{-3}$ and $\mathrm{BC}$ mass concentrations of 
$1.30 \mu \mathrm{g} \mathrm{m}^{-3}$ in the first days of May before the initiation of the anticyclone blocking. Clean air conditions with respect to the accumulation mode load $\left(\sim 200\right.$ particles $\left.\mathrm{cm}^{-3}\right)$ occur for air masses arriving from the north with increasing concentrations if the wind direction turns towards northeast or northwest.

At the Mace Head station, accumulation mode particle concentrations were 100 particles $\mathrm{cm}^{-3}$ five days before measurement flights were conducted south west of Ireland to measure polluted air masses from Central Europe and Great Britain. BC-mass minimum concentrations at this time were $0.05 \mu \mathrm{g} \mathrm{m}^{-3}$. These observed minima were associated with wind directions from north and northeast. On 12 May the concentrations increased up to 2500 particles $\mathrm{cm}^{-3}$ and BC-mass of $1.5 \mu \mathrm{g} \mathrm{m}^{-3}$ while the wind direction changed to $\mathrm{E}$ and continental European air masses were advected over Mace Head. The transport of European emissions towards Ireland was caused by the displacement of the anticyclone from the North Sea into the North East Atlantic and the pathway of cyclones over Southern Europe.

\subsubsection{Remote ground stations within the high pressure core region}

\section{Vavihill and Hohenpeißenberg}

The median accumulation mode number concentrations at the second Scandinavian station at Vavihill (Fig. 6) were 760 particles $\mathrm{cm}^{-3}$ and 530 particles $\mathrm{cm}^{-3}$ during period (a) and period (b), respectively. The prevailing wind direction averaged over period (a) was northwest. Minimum number concentrations occurred when the wind direction turned to north. A cold front occurred on 12 May and was accompanied by a shift of wind direction to east and followed by a decrease of accumulation mode number concentrations to 120 particles $\mathrm{cm}^{-3}$ after a short prefrontal increase to 2500 particles $\mathrm{cm}^{-3}$. The cold front was induced by a cyclone with its centre situated at Northern Scandinavia. It mainly increased the cloud cover but induced hardly any precipitation over Vavihill. A following maximum in accumulation mode particle number concentrations $\left(\sim 1500\right.$ particles $\left.\mathrm{cm}^{-3}\right)$ occurred during air mass transport from west and southwest, covering the source regions of Copenhagen (Denmark), Helsingborg, and Malmo (both Sweden). On the top of the Hohenpeißenberg (977 m a.s.l., Fig. 7) accumulation mode number concentrations during period (a) exceeded the concentrations during period (b) by a factor of approximately 1.5. A similar factor could be observed at Vavihill (see Table 3). Median accumulation mode number concentrations reached during anticyclonic conditions 1000 particles $\mathrm{cm}^{-3}$, median BCmass concentrations $0.39 \mathrm{\mu g} \mathrm{m}^{-3}$, and winds were easterly at Hohenpeißenberg. Frontal passages occurring between 15 and 19 May and inducing precipitation and change in wind direction towards west led to a decrease of the median accumulation mode number concentration (680 particles $\mathrm{cm}^{-3}$ ). Median BC-mass concentrations remained almost at the same level.

\subsubsection{Ground stations within the high pressure core region}

\section{Melpitz and Cabauw}

The accumulation mode number concentrations at Melpitz (Fig. 8) varies between 690 and 2300 particles $\mathrm{cm}^{-3}$. Median values were 1400 particles $\mathrm{cm}^{-3}$ for period (a) and 1300 particles $\mathrm{cm}^{-3}$ for period (b). Prevailing wind direction during the anticyclonic conditions was northeast and air masses were transported towards Melpitz via the Baltic Sea and the Baltic States. As described in Sect. 3 the westerly flow over Melpitz starting on 15 May lasted only 4 days and turned back to a northeasterly flow similar to period (a). Within this 4 day period frontal systems associated with two cyclones passed consecutively over Melpitz and a short decrease of the pollutants could be observed. The time series of BC-mass concentration varies between 0.12 and $0.89 \mu \mathrm{g} \mathrm{m}^{-3}$. Both accumulation mode number concentration and BC-mass concentration time series follow a clear diurnal cycle with maximum concentrations in the morning and minimum concentrations in the afternoon. Maximum peaks could be observed at 3500 particles $\mathrm{cm}^{-3}$ and $1.50 \mu \mathrm{g} \mathrm{m}^{-3}$. These maximum peaks are connected with wind directions $\mathrm{W}$ or $\mathrm{E}$ and can be associated with local sources like e.g. the open-cast mining area Lausitz east of Melpitz or with long-range transport events from Central and Eastern Europe (Spindler et al., 2010).

The diurnal variation described for the Melpitz station was also observed at the Cabauw station (Fig. 9). During period (a), daily averages of $\mathrm{BC}$-mass concentrations increased from 0.50 to $1.40 \mu \mathrm{g} \mathrm{m}^{-3}$. Maximum peaks of the running average occur again in the morning and minima at early afternoon times. Absolute minimum and maximum BC-mass concentration of the highly variable time series were between approximately $0.00-2.50 \mu \mathrm{g} \mathrm{m}^{-3}$. The anticyclone induced an easterly wind direction over Cabauw. Decreasing concentrations of accumulation mode particles from 3500 to 500 particles $\mathrm{cm}^{-3}$ and $\mathrm{BC}$-mass from 1.30 to $0.20 \mu \mathrm{g} \mathrm{m}^{-3}$ were associated with the passage of two frontal systems occurring between 15 and 17 May and the change of the wind direction from east to northeast and north. Air mass trajectories calculated with LAGRANTO (Wernli and Davies, 1997; Stohl et al., 2001) using the ECMWF wind field showed that the change of the wind direction resulted in a change from polluted air masses arriving from North Germany to clean air masses advected over the North Sea towards Cabauw. The concentrations increased again for wind directions turning back to $\mathrm{E}$ between 21 May and 23 May. 


\subsubsection{Comparison of accumulation mode time series with $\mathrm{BC}$ time series}

The time series of pollutants show week correlation between the different ground stations. However, at each single ground station the time series of accumulation mode number and BC-mass concentrations show similar trends. This similar pattern in the temporal evolution indicates that air masses containing a high load of accumulation mode particles mainly originate from regions rich in sources of anthropogenic emissions from combustion processes (Hitzenberger and Tohno, 2001; Putaud et al., 2004). Figure 10 supports this observation. It shows the relative variation of $\mathrm{BC}$-mass concentrations $(M)$ in the last $6 \mathrm{~h}\left(M_{i}-M_{i-6}\right) / M_{i-6}$ versus the relative variation of accumulation mode number concentrations $(N)$ in the last $6 \mathrm{~h}\left(N_{i}-N_{i-6}\right) / N_{i-6}$ where $i$ is the time in hours. The correlation coefficient $r$ obtained by linear regression varies between 0.53 (Melpitz) and 0.86 (Hohenpeißenberg). The correlation at all ground stations can be denoted as statistically significant on a $99 \%$ confidence level. This means that in most cases the relative variation of one pollutant is accompanied by the relative variation of the other one. During several pollution events the Central European ground stations showed a stronger increase of the BC-mass concentrations than the accumulation mode number concentrations. Different sources, source strengths and transport processes can contribute to different fractions of $\mathrm{BC}$ particles in different aerosol size ranges (e.g., Berner et al., 1996; Hitzenberger and Tohno, 2001; Rose et al., 2006). Thus the relative variations of the accumulation mode particle concentrations and the BC-mass concentrations can differ in magnitude, although both were affected by similar anthropogenic sources.

\subsubsection{Average BC distribution over Europe}

FLEXPART simulations are used to analyse the average horizontal BC-mass distributions over Europe for period (a) and period (b) that result from European anthropogenic emissions. They are compared to the average BC-mass concentrations measured at the ground stations during the respective period. As discussed above an increase of BC-mass concentration goes along with an increase of accumulation mode number concentration in most cases that were observed at the ground stations. Thus, regions of increased BC-mass concentrations can be associated with regions of increased particulate matter. Fig. 11 shows the average BC distribution above Europe at $10 \mathrm{~m}$ a.g.l. The average values were calculated for period (a) and period (b) from FLEXPART simulations on a $1^{\circ} \times 1^{\circ}$ grid. The circles indicate the position of the ground stations and the colour shade the average $\mathrm{BC}$-mass concentration measured at the ground stations during period (a) and (b). Maximum BC-mass concentrations greater than $0.7 \mu \mathrm{g} \mathrm{m}^{-3}$ can be found above the Benelux States, north-east France, the English Channel, and England.
A second maximum can be found above southern Poland. Compared to period (b), the regions of maximum BC-mass concentrations have a larger horizontal extension. In contrast, BC-mass concentrations greater than $0.7 \mu \mathrm{g} \mathrm{m}^{-3}$ were mostly limited to urban regions like London, Paris or Rotterdam. The FLEXPART simulations also show that the anticyclonic transport associated with the high pressure system centred over the North Sea and Denmark led to a transport of anthropogenic pollution towards the Atlantic and the Norwegian Sea. The average values retrieved from the FLEXPART simulations agree well with the observed temporal averages and lie within $25 \%$ of the measured BC-mass concentrations.

\subsection{Temporal evolution of the $C N$ number concentration over South Germany}

To summarize the vertical distribution and temporal evolution of the pollution situation, the vertical profiles over Southern Germany are examined. During take off from and landing to Oberpfaffenhofen a set of vertical profiles were obtained covering the whole time span of the EUCAARILONGREX campaign. Vertical $C N$ profiles are compared to the $C N$ concentrations measured at Hohenpeißenberg located about $35 \mathrm{~km}$ south west of Oberpfaffenhofen.

Figure 12 shows the $C N$ number concentration measured during the vertical profiling with the DLR Falcon 20 and the time series of the $C N$ number concentration measured at Hohenpeißenberg in May 2008. In addition the mixing layer height at each day at 12:00 UTC is shown. The mixing layer height was retrieved from radio soundings launched at Oberschleißheim/Munich ( $489 \mathrm{~m}$ a.s.l.) using the simple parcel method (Holzworth, 1964; Seibert et al., 2000). This gives the possibility to study a continuous evolution of the mixing layer height in the region of Munich $(28 \mathrm{~km}$ northeast of Oberpfaffenhofen, $65 \mathrm{~km}$ northeast of Hohenpeißenberg).

In the first half of May during the stable anticyclonic conditions median $C N$ number concentrations in the free troposphere above $3 \mathrm{~km}$ a.s.l. were about $840-1200$ particles $\mathrm{cm}^{-3}$ (see Table 4). Median values inside the boundary layer reached 8200 particles $\mathrm{cm}^{-3}$. The boundary layer was well mixed vertically and increased in depth to $3.1 \mathrm{~km}$ above ground until 14 May. The time series at Hohenpeißenberg also showed maximum number concentrations within in the first half in May. The $C N$ number concentrations measured at the ground station occasionally reached 10000 particles $\mathrm{cm}^{-3}$, but median concentrations were at 3600 particles $\mathrm{cm}^{-3}$. The vertical profile for period (a) shows that median number concentrations were highest in a layer between $1300-1600 \mathrm{~m}$ (12000 particles $\mathrm{cm}^{-3}$; Fig. 12). With the change of the meteorological conditions, the change of wind directions and the occurrence of precipitation beginning on 15 May, number concentrations decreased and reached 2300 and 2700 particles $\mathrm{cm}^{-3}$ for airborne measurements blow $3 \mathrm{~km}$ a.s.l. and at Hohenpeißenberg, respectively. The vertical structure changed with changing synoptic conditions, 

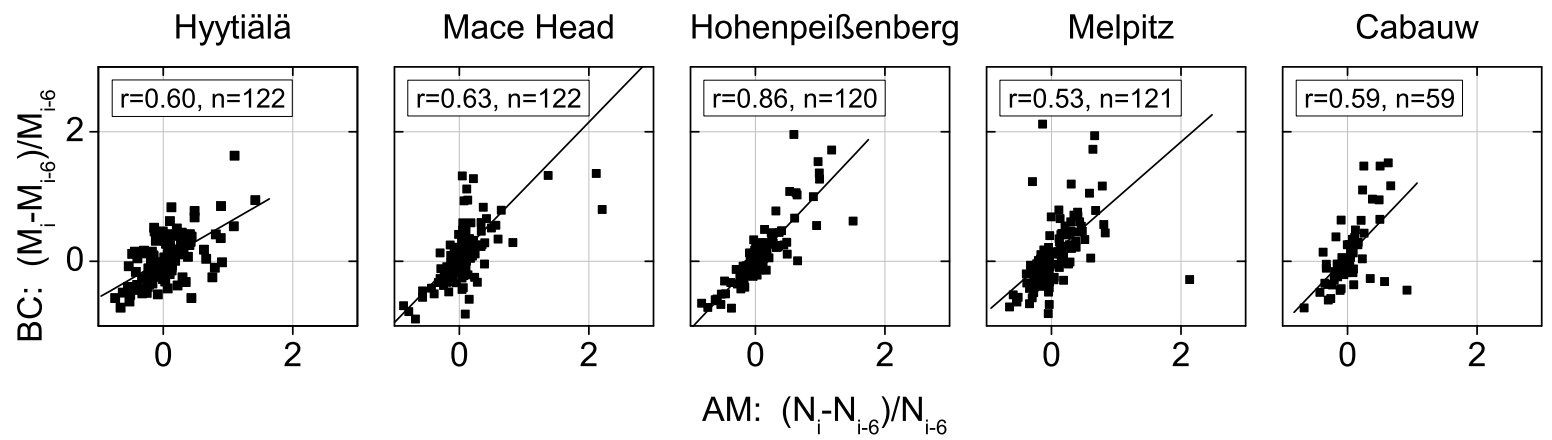

AM: $\left(\mathrm{N}_{\mathrm{i}}-\mathrm{N}_{\mathrm{i}-6}\right) / \mathrm{N}_{\mathrm{i}-6}$

Fig. 10. Relative increase (decrease) of 6 hourly averaged BC-mass concentrations versus relative increase (decrease) of 6 hourly averaged accumulation mode number concentrations. The legend indicates the regression coefficient $r$ and the number of points $n$.
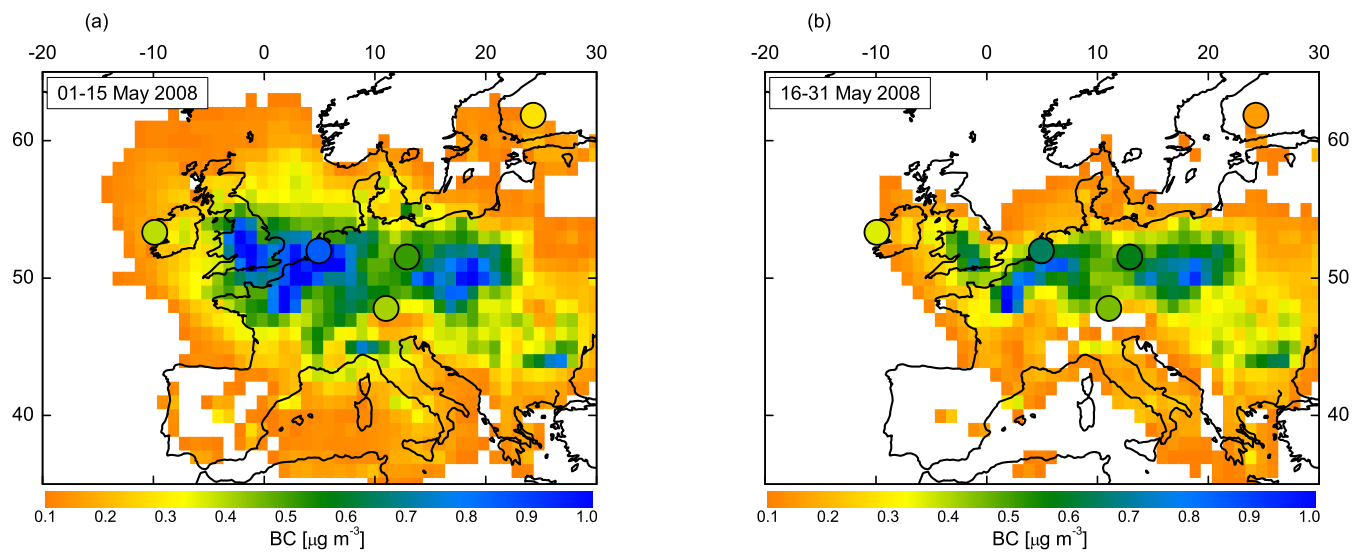

Fig. 11. Average BC-mass distribution over Europe at $10 \mathrm{~m}$ a.g.l from FLEXPART simulations averaged on a $1^{\circ} \times 1^{\circ}$ grid. Panel (a) shows average values for period (a), panel (b) shows average values for period (a). The circles indicate average BC-mass concentrations measured at Mace Head, Cabauw, Hohenpeißenberg, Melpitz, and Hyytiälä (station names are listed from West to East) for period (a) and (b), respectively.

too. The well mixed boundary layer shows a heterogeneous layering in the second half of May. The maximum mixing layer height during period (b) occurs on 21 May at $1.8 \mathrm{~km}$ above ground. Layers of enhanced $C N$ number concentrations could be observed in the upper troposphere above $6 \mathrm{~km}$ a.s.l. We suggest that this enhancement in the upper troposphere primarily occurs due to long-range transport of air masses which was inhibited during period (a) by the anticyclonic blocking.

A comparison with previous airborne measurements performed from Oberpfaffenhofen (SCAVEX April/May 2001 and SCAVEX April 2002) reveals the highly polluted boundary layer observed during EUCAARI-LONGREX over Southern Germany (see Table 4 and Fig. 13). The number concentrations between $0-3 \mathrm{~km}$ a.s.l. during period (b) of 2300 particles $\mathrm{cm}^{-3}$ lay in between the values of the two SCAVEX campaigns (3300 and 2100 particles $\mathrm{cm}^{-3}$, respectively). In contrast, the number concentrations during the high pressure conditions of period (a) exceed these values with a median number concentration of 8200 particles $\mathrm{cm}^{-3}$.

\subsection{Comparison between airborne and ground based measurements}

One objective of the EUCAARI-LONGREX campaign was to link the measurements at the ground stations within the EUCAARI intensive observing period to the airborne measurements in order to assess the spatial and, in particular, vertical representativeness of the ground measurements. We focus here on the comparison of accumulation mode number concentrations because of its small variability within the aerosol lifetime inside a given air mass (Williams et al., 2002). Thus, in the absence of sources, the spatial variation inside the given air mass should also remain small.

Figure 14 shows the accumulation mode number concentration of airborne measurements versus ground based 
Table 3. Median, 10-th and 90-th percentile values of the accumulation mode number concentration, BC mass concentration and sea level pressure at the selected ground stations. The averaging time was split up into two periods. Period (a) lasts from 1 May 2008 until 15 May 2008, period (b) from 16 May 2008 until 31 May 2008.

\begin{tabular}{lcccccccccc}
\hline & \multicolumn{3}{c}{$\mathrm{N}_{0.1-0.8 \mathrm{~m}}\left(\mathrm{~cm}^{-3}\right)$} & \multicolumn{3}{c}{$\mathrm{BC}\left(\mu \mathrm{g} \mathrm{m}^{-3}\right)$} & \multicolumn{4}{c}{$\mathrm{SLP}(\mathrm{hPa})$} \\
Ground site & Median & $\mathrm{P} 10$ & $\mathrm{P} 90$ & Median & $\mathrm{P} 10$ & $\mathrm{P} 90$ & Median & P10 & P90 & Period \\
\hline Hyytiälä & 330 & 120 & 1300 & 0.17 & 0.03 & 0.74 & 1019 & 1014 & 1024 & $\mathrm{a}$ \\
& 360 & 190 & 610 & 0.15 & 0.06 & 0.26 & 1019 & 1007 & 1026 & $\mathrm{~b}$ \\
Mace Head & 550 & 82 & 1900 & 0.23 & 0.03 & 0.96 & 1017 & 1007 & 1022 & $\mathrm{a}$ \\
& 830 & 520 & 1500 & 0.33 & 0.18 & 0.55 & 1013 & 1007 & 1018 & $\mathrm{~b}$ \\
Vavihill & 760 & 280 & 1200 & & & & 1022 & 1016 & 1029 & $\mathrm{a}$ \\
Hohenpeißenberg & 530 & 300 & 820 & & & & 1019 & 1005 & 1023 & $\mathrm{~b}$ \\
& 1000 & 380 & 1400 & 0.39 & 0.20 & 0.59 & 1017 & 1013 & 1024 & $\mathrm{a}$ \\
Melpitz & 680 & 270 & 1300 & 0.40 & 0.14 & 0.72 & 1011 & 1007 & 1014 & $\mathrm{~b}$ \\
Cabauw & 1400 & 690 & 2300 & 0.44 & 0.12 & 0.89 & 1021 & 1015 & 1027 & $\mathrm{a}$ \\
& 1300 & 760 & 1900 & 0.56 & 0.19 & 1.00 & 1014 & 1007 & 1017 & $\mathrm{~b}$ \\
& & & & 0.70 & 0.06 & 1.50 & 1019 & 1014 & 1026 & $\mathrm{a}$ \\
& 1700 & 490 & 3100 & 0.54 & 0.18 & 1.20 & 1012 & 1007 & 1018 & $\mathrm{~b}$ \\
\hline
\end{tabular}

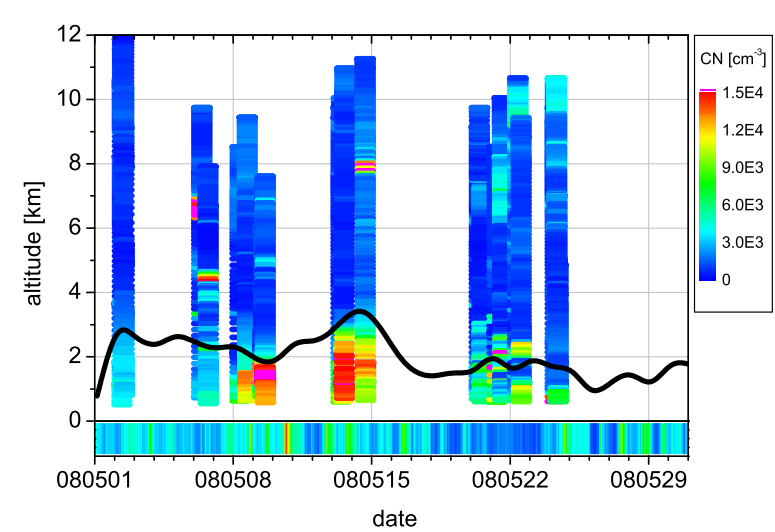

Fig. 12. Vertical profiles of $C N$ number concentrations in the vicinity of Hohenpeißenberg. The colour scale indicates the $C N$ number concentration between 0 (blue) and 15000 (red) particles $\mathrm{cm}^{-3}$. Concentrations exceeding 15000 particles $\mathrm{cm}^{-3}$ are marked in magenta. Airborne measurements are given at standard temperature and pressure (STP). The mixing layer height retrieved from soundings at Oberschleißheim/Munich at 12:00 UTC is shown as the black line with height shown on the left hand side vertical axis. The time series on the bottom of the graph depicts the $C N$ number concentration measured at the ground station at Hohenpeißenberg.

measurements to illustrate the correlation between airborne and ground based measurements. The data used for the flight sequences were measured inside the boundary layer with a maximum distance of $150 \mathrm{~km}$ to the respective ground station. Each sequence covers one flight leg, i.e. a sequence during the flight when the aircraft was heading towards one direction on a constant level. The flight legs cover a large spatial area $(\sim 50 \mathrm{~km}$ per flight leg) but a short time span
( $\sim 5$ min per flight leg). The data of the ground based measurements were averaged using a time span of $\pm 3 \mathrm{~h}$ around the time, when the flight legs close to the stations were performed.

The correlation coefficient was 0.76 for FAAM BAe-146 measurements and 0.82 for DLR Falcon 20 measurements. The lower value of the correlation coefficient for FAAM BAe-146 measurements results from more frequent observations in more heterogeneous air masses as can be concluded from the higher standard deviations shown in Fig. 14. The correlation of ground based and airborne measurements within the standard deviation of the selected sequences can be denoted as statistically significant on a $99 \%$ confidence level. Hence the assumption can be made that the selected flight sequences were performed within the same air mass as the one that was probed by the ground stations with respect to temporal relatively stable aerosol properties.

\section{Discussion}

The overview on the meteorological and the pollution situation during the EUCAARI-LONGREX campaign presented in the previous sections helps to gain insight into the effects of synoptic events on the distribution of anthropogenic emissions over Europe. During the stable anticyclonic blocking event in May 2008 pollutants accumulated within the core region of the anticyclone due to the absence of thick cloud cover and precipitation and the inhibition of mixing of particles from the boundary layer into the free troposphere. The anticyclone's core was centred mainly over the Benelux states, the northern part of Germany and Denmark. The anticyclonic blocking event and its stationary position was a special though not exceptional synoptic situation (Sect. 4). 
Table 4. $C N$ number concentration median, 10-th and 90-th percentile values calculated from altitude bins with a thickness of $3 \mathrm{~km}$ each. Concentrations are given at standard temperature and pressure (STP). The vertical profiles were measured during ascend and descend from and to Oberpfaffenhofen by the DLR Falcon 20 during several measurement campaigns. The measurements during the EUCAARI campaign in 2008 were split up into two periods, period a from 1 May 2008 until 15 May 2008 and period b from 16 May 2008 until 31 May 2008. The SCAVEX campaigns took place in April/May 2001 and April 2002. Number concentrations are given in particles $\mathrm{cm}^{-3}$.

\begin{tabular}{llccc}
\hline Altitude & Campaign & Median & P10 & P90 \\
\hline 9-12 km & EUCAARI & 1200 & 730 & 3500 \\
& EUCAARI a & 1100 & 690 & 1700 \\
& EUCAARI b & 1600 & 760 & 4600 \\
& SCAVEX 01 & 680 & 450 & 1300 \\
& SCAVEX 02 & 310 & 170 & 470 \\
$6-9 \mathrm{~km}$ & EUCAARI & 1200 & 620 & 2700 \\
& EUCAARI a & 1200 & 560 & 2000 \\
& EUCAARI b & 1400 & 720 & 3400 \\
& SCAVEX 01 & 970 & 520 & 2100 \\
& SCAVEX 02 & 350 & 160 & 840 \\
$3-6 \mathrm{~km}$ & EUCAARI & 820 & 400 & 2000 \\
& EUCAARI a & 840 & 370 & 2200 \\
& EUCAARI b & 800 & 470 & 1800 \\
& SCAVEX 01 & 880 & 490 & 2100 \\
& SCAVEX 02 & 910 & 97 & 1600 \\
$0-3 \mathrm{~km}$ & EUCAARI & 5500 & 970 & 13000 \\
& EUCAARI a & 8200 & 1000 & 14000 \\
& EUCAARI b & 2300 & 930 & 8300 \\
& SCAVEX 01 & 3300 & 1200 & 13000 \\
& SCAVEX 02 & 2100 & 650 & 5700 \\
\hline \multirow{5}{*}{ HPB } & EUCAARI & 3300 & 1600 & 6000 \\
& EUCAARI a & 3600 & 2500 & 6300 \\
& EUCAARI b & 2700 & 1400 & 5700 \\
\hline
\end{tabular}

Several climatologies of blocking events have shown that the European Atlantic region, at the end of the Atlantic storm track, is the region with the highest frequency of blocking events followed by the eastern Pacific region (e.g., Barriopedro et al., 2006; Tyrlis and Hoskins, 2008). The annual cycle shows maximum frequencies in the cold season. A primary blocking episode genesis area for the eastern Atlantic region was found at $0^{\circ}$ longitude (Barriopedro et al., 2006), compared to approximately $5^{\circ} \mathrm{E}$ for the blocking in May 2008 . The described blocking was located between $50^{\circ} \mathrm{N}-60^{\circ} \mathrm{N}$, the latitude where most blocking events occur. The mean duration of blocking events over Europe was found to be between 7.6-8 days (Tyrlis and Hoskins, 2008). Thus, the blocking event in May 2008 which lasted 12 days, was exceptionally persistent.

The transport of continental air masses caused by the anticyclonic conditions led to pollution events in regions usually dominated by clean atmospheric conditions, i.e. at the ground sites at Hyytiälä and Mace Head. Hyytiälä usually observes clean air conditions with respect to aged anthro- pogenic pollution especially for wind directions from $\mathrm{N}$ and NW leading to conditions favourable for new particle formation (Tunved et al., 2003; Sogacheva et al., 2005). However two distinct pollution events could be observed during period (a). The first event during the onset of the anticyclone showed the maximum concentrations of accumulation mode number and BC-mass in May 2008 at the station. The wind direction occurring during this event (ESE) and FLEXPART analysis show that the air masses originated from Eastern $\mathrm{Eu}-$ rope. The measured BC-mass concentrations for this case exceeded values observed for long-range transport cases from Eastern Europe during preceding studies (Niemi et al., 2009). The second pollution event lasted from 8 May until 12 May. It can be associated with the transport of Central European pollution within the anticyclone. However, the concentrations of the pollutants within the Central European air masses are smaller by a factor of 2-3 than the concentrations within the Eastern European air masses.

Analysis of the accumulation mode number concentrations using $\mathrm{CO}$ as inert pollution tracer (not shown here) indicate that this is mainly an effect of mixing with clean Arctic air masses during transport. However, washout of particles due to the frequently occurring precipitation at the Norwegian mountain range cannot be neglected.

A detailed analysis of aerosol microphysical and chemical properties during the EUCAARI intensive observing period at Mace Head was accomplished by Dall'Osto et al. (2010). In general the site provides favourable conditions for the study of natural air pollution like sea-salt or biogenic organic aerosol resulting from phytoplankton blooms (O'Connor et al., 2008). Roughly $20 \%$ of the air masses arriving at Mace Head per year, originate from continental Europe. They are most frequently observed in May (Huang et al., 2001; Junker et al., 2006). Due to the eastward transport of continental air masses induced by the blocking anticyclone in May 2008 continental European emissions could be measured at the Mace Head station. As discussed in Sect. 5.1 two pollution events were observed in May 2008 before the beginning of the intense observing period at the ground stations on 15 May. These two events were followed by a continuous occurrence of continental pollution until the end of May (Dall'Osto et al., 2010). Minimum values of accumulation mode number and BC-mass concentrations at the beginning of May were comparable to typical clean marine conditions in spring and summer (Cooke et al., 1997; Yoon et al., 2007).

A more continuously increased level of accumulation mode number concentrations related to the blocking event was observed at the continental background stations at Vavihill and Hohenpeißenberg. Both stations did not show the diurnal cycle of accumulation mode number and BC-mass concentrations which could be observed at Melpitz and Cabauw. The latter two stations showed minimum concentrations in the afternoon and maximum concentrations in the morning. Diurnal cycles of particulate matter in urban areas have been 


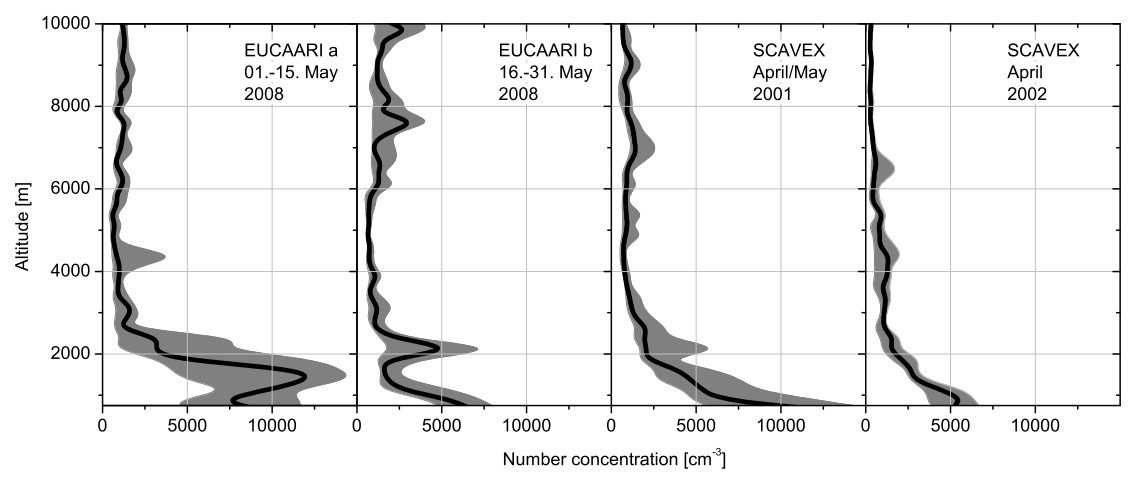

Fig. 13. Comparison of the vertical distribution of total particle number concentrations during the EUCAARI-LONGREX campaign (May 2008) and the two SCAVEX campaigns (April/May 2001 and April 2002). Thick black lines indicate the median values of bins with a vertical depth of $250 \mathrm{~m}$, gray shade values between 25-th and 75-th percentiles. Concentrations are given at standard temperature and pressure (STP).

analysed in several previous studies (e.g., Kukkonen et al., 2005; Schäfer et al., 2006; Pernigotti et al., 2007; Pitz et al., 2008). Minimum concentrations of particulate matter frequently occur in the afternoon hours in polluted and urban background regions. Vertical mixing during unstable stratification of the boundary layer due to surface heating during daytime leads to mixing of surface pollution into upper regions inside the increasing boundary layer. In contrast nocturnal temperature inversion close to the surface increases the vertical stability and consequently inhibits extensive vertical mixing of pollutants. Increasing traffic intensity in the morning is an additional dominating factor for increasing concentrations of pollutants.

The ground station at Melpitz is located in a region affected by several anthropogenic pollution sources (Hamed et al., 2010). Wind directions at Melpitz were most frequently NE for period (a) as well as for period (b). Thus air masses were transported towards Melpitz via the Baltic Sea and the Baltic states. For similar transport conditions Engler et al. (2007) observed similar accumulation mode number concentrations of 1100-1400 particles $\mathrm{cm}^{-3}$. The accumulation mode number concentrations measured during period (a) $\left(1400 \mathrm{~cm}^{-3}\right)$ and period (b) $\left(1300 \mathrm{~cm}^{-3}\right)$ also coincide with values for aged continental aerosol of 1200 particles $\mathrm{cm}^{-3}$ given by Birmili et al. (2001). Highest aerosol mass loadings usually occur during temperature inversion periods in wintertime (Müller, 1999). Spindler et al. (2010) reported elevated aerosol mass loadings during spring and summer, although not as high as during wintertime, for hot and dry meteorological periods. The four year study at Melpitz showed that elevated aerosol mass concentrations occurred in May 2008, but were below elevated mass concentrations observed in summer 2006 and spring 2007.

Highest median concentrations of anthropogenic pollutants at all six ground stations were observed at Cabauw during period (a) (BC mass $0.70 \mu \mathrm{g} \mathrm{m}^{-3}$, see Table 3). This is in agreement with the previously discussed transport of pollution from Germany towards the West and the Benelux states during the anticyclonic blocking event.

$C N$ number concentrations were analysed for particles larger than $10 \mathrm{~nm}$ in diameter. The median $C N$ concentrations over South Germany of the ground based $\left(3600 \mathrm{~cm}^{-3}\right)$ and airborne measurements below $3 \mathrm{~km}\left(8200 \mathrm{~cm}^{-3}\right)$ show quite large discrepancies regarding the absolute concentrations during period (a). The DLR Falcon 20 mainly flew above or west of Munich during take off from and landing to Oberpfaffenhofen, i.e. downwind of Munich during period (a). Thus rather fresh emissions from Munich were observed aboard the aircraft whilst the ground station at Hohenpeißenberg, $55 \mathrm{~km}$ southeast of the Munich, mainly measured the enhanced background aerosol concentrations during period (a). This local variation of $C N$ number concentrations also emphasises the use of the less variable accumulation mode size range (Williams et al., 2002) for the comparison of absolute number concentrations between airborne and ground based measurements in Sect. 5.3.

The $C N$ number concentrations serve to illustrate the vertical aerosol distribution (see Fig. 13). Whilst an almost continuous negative vertical gradient from the surface to the top of the boundary layer can be observed for period (b) and the two SCAVEX cases, the high number concentrations partly originating from the emissions of Munich occur throughout the whole vertical column of the boundary layer during period (a). Therefore a much more pronounced negative vertical gradient appears immediately above the polluted boundary layer at the intersection into the clean free troposphere. This is evident already from the averaged vertical profile in Fig. 13, which tends to smooth out the vertical gradients on a case by case basis because of varying boundary layer height. The gradient can be illustrated by the differences of the median values between $0-3 \mathrm{~km}$ and $3-6 \mathrm{~km}$ in Table 4 . Whilst the number concentrations decreased with height by 


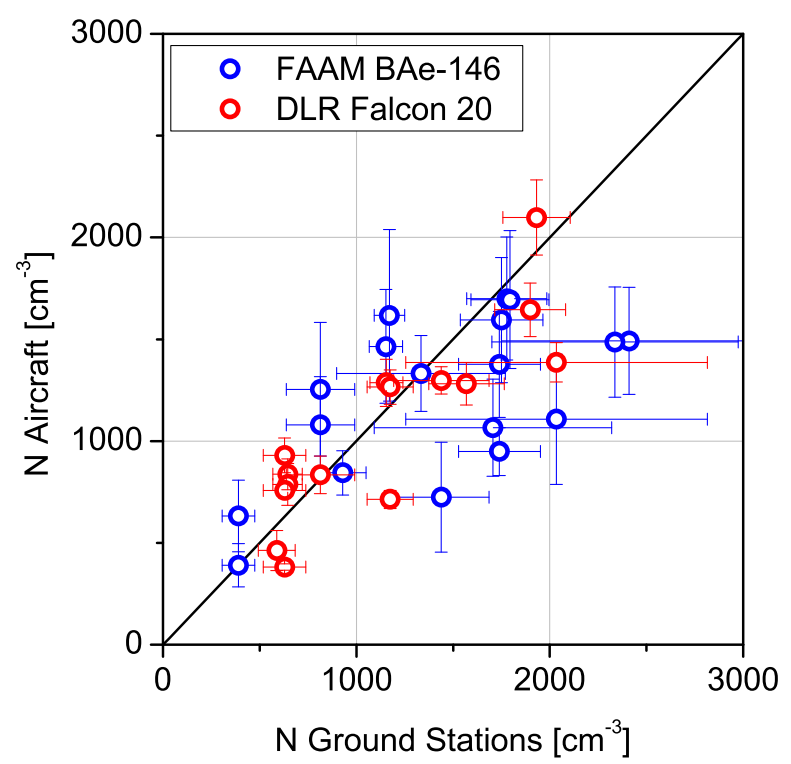

Fig. 14. Comparison of accumulation mode particle number concentrations (particle diameter $0.1-0.8 \mu \mathrm{m}$ ) from ground based measurements with airborne measurements. Blue circles denote FAAM BAe-146, red circles DLR Falcon 20 data points. Airborne measurements are given at standard temperature and pressure (STP).

a factor 10 during period (a), the number concentrations during period (b) and the two SCAVEX cases decreased by a factor 2-4. This reflects the stable layering of the troposphere during period (a) and suggests a trapping of anthropogenic pollution particles during high pressure conditions inside the boundary layer.

One can conclude that the anticyclonic blocking event led to an accumulation of anthropogenic pollution inside the boundary layer due to slower transport of locally produced pollutants as observed by, e.g., Vignati et al. (1999). Only regions inside the core of the anticyclone were affected by a continuous high load of anthropogenic pollutions. However one has to consider that the region which was directly affected by the anticyclone has a size of roughly $1000 \mathrm{~km}$ in diameter. Inside this large area anthropogenic emissions of a multiplicity of sources could mix within the boundary layer. Long-range transport of the pollution from Central Europe led to pollution events outside the core region of the anticyclone.

\section{Conclusions}

A basic examination of the synoptic and pollution situation over Europe during the EUCAARI-LONGREX campaign was accomplished using model data and ground based and airborne measurements. This analysis gives an overview of the conditions during the campaign. Detailed analyses of the results of the EUCAARI-LONGREX campaign are given in accompanying papers (Mirme et al., 2010; Morgan et al., 2010; McMeeking et al., 2010).

In the first half of May 2008 a stable anticyclone blocking evolved over Central Europe with its core located over the North Sea and Denmark. The subsiding air masses led to mostly clear sky conditions over the influenced regions. The anticyclonic transport of air masses followed a path from Scandinavia via the Baltic Sea to Poland and Germany, from Germany over the Benelux States and the English Channel towards Great Britain and from Great Britain via the Norwegian Sea back to Scandinavia. Within the core region of the anticyclone Central European pollutions were partly recirculated via the North Sea and Southern Scandinavia to Northern Germany. Air masses arriving at Hyytiälä from northwest within in the anticyclonic transport showed lower concentrations of accumulation mode particles and BC-mass compared to Central European regions but could be identified as distinct pollution events in the typically clean environment (accumulation mode number: $330 \mathrm{~cm}^{-3}$, BC-mass: $0.17 \mu \mathrm{g} \mathrm{m}^{-3}$ ). Increasing concentration of pollutants could be observed following the transport pathway towards the south at the ground stations at Vavihill (accumulation mode number: $760 \mathrm{~cm}^{-3}$ ) and Melpitz (accumulation mode number: $1400 \mathrm{~cm}^{-3}$, BC-mass: $\left.0.44 \mu \mathrm{g} \mathrm{m}^{-3}\right)$. Maximum pollution was found at Cabauw after the westward transport of air masses from Germany and the uptake of anthropogenic emissions. Median BC-mass concentrations during the anticyclonic conditions were $0.70 \mu \mathrm{g} \mathrm{m}^{-3}$ at Cabauw. Due to the synoptic conditions the highly polluted air masses were advected via South England to Ireland and into the Atlantic southwest of Ireland and could be observed at the Mace Head ground station.

The combination of ground based and airborne measurements shown in Sect. 5.3 allow for the interpretation of the measurement flights inside the spatial and temporal framework given by the ground stations. The ground based data can now also be extended into the vertical column using the vertical profile measurements of FAAM BAe-146 and DLR Falcon 20.

The vertical structure of the $C N$ number concentration showed a very stable layering under the high pressure conditions. The vertical column inside the boundary layer was well mixed but hardly any particulate pollution could escape into the free troposphere. After the anticyclone dissolved the vertical structure appeared much more heterogeneous. Removal of particles by precipitation and mixing of pollutants into the free troposphere associated with unstable thermal stratification and resulting convection led to a less distinct layering of the atmosphere. Increased number concentrations throughout the upper troposphere above $6 \mathrm{~km}$ indicated occasional new particle formation during the second half of May 2008, which was inhibited by subsiding air masses before, and long range transport arriving over Europe, which was blocked before by the anticyclone. 
The meteorological evolution over Europe during the EUCAARI-LONGREX campaign allows studying European pollution at two different distinct synoptic situations. Especially the blocking anticyclone in the first half of May 2008 led to stable meteorological conditions over Central Europe. This blocking anticyclone was not exceptional and a type of event occurring typically 1-2 times in the season between April and June per year. Such events lead to accumulation of particulate pollutants inside the boundary layer as this study has shown for the May 2008 blocking event. The airborne measurements performed during the EUCAARI-LONGREX campaign allowed to investigate the evolution of pollution on a continental scale at well defined meteorological conditions. Further analysis of the airborne measurements covering aerosol microphysical properties like aerosol mixing state and properties of aerosol size distributions as well as a detailed transport analysis of the probed air masses will be examined in a forthcoming paper.

Acknowledgements. This work has been partly funded by EUCAARI (European Integrated project on Aerosol Cloud Climate and Air Quality interactions) No. 036833-2. It was also performed in the framework of the Research Infrastructure Action under the FP6 Structuring the European Research Area Programme, EUSAAR Contract No. RII3-CT-2006-026140. The authors like to thank the staff member of the measurement sites and the teams working on the airborne measurements aboard the FAAM BAe-146 and DLR Falcon 20 during the EUCAARILONGREX campaign. The authors especially want to thank Andreas Dörnbrack for his work and help on the meteorological forecast during the campaign and the subsequent analysis. More information about EUCAARI-LONGREX can be found on http://www.pa.op.dlr.de/aerosol/eucaari2008/.

Edited by: V.-M. Kerminen

\section{References}

Barriopedro, D., García-Herrera, R., Lupo, A. R., and Hernández, E.: A climatology of Northern Hemisphere blocking, J. Climate, 19, 1042-1063, 2006.

Berner, A., Sidla, S., Galambos, Z., Kruisz, C., Hitzenberger, R., ten Brink, H. M., and Kos, G. P. A.: Modal character of atmospheric black carbon size distributions, J. Geophys. Res., 101, 1955919565, 1996.

Berner, A., Galambos, Z., Ctyroky, P., Frühauf, P., Hitzenberger, R., Gomiscek, B., Hauck, H., Preining, O., and Puxbaum, H.: On the correlation of atmospheric aerosol components of mass size distributions in the larger region of a central European city, Atmos. Environ, 38, 3959-3970, 2004.

Birmili, W., Wiedensohler, A., Heintzenberg, J., and Lehmann, K.: Atmospheric particle number size distribution in central Europe: Statistical relations to air masses and meteorology, J. Geophys. Res., 106, 32005-32018, 2001.

Cooke, W. F., Jennings, S. G., and Spain, T. G.: Black carbon measurements at Mace Head, 1989-1996, J. Geophys. Res., 102, 25339-25346, 1997.
Dall'Osto, M., Ceburnis, D., Martucci, G., Bialek, J., Dupuy, R., Jennings, S. G., Berresheim, H., Wenger, J. C., Healy, R. M., Facchini, M. C., Rinaldi, M., Giulianelli, L., Finessi, E., Worsnop, D., Ehn, M., Mikkilä, J., Kulmala, M., and O’Dowd, C. D.: Aerosol properties associated with air masses arriving into the North East Atlantic during the 2008 Mace Head EUCAARI intensive observing period: an overview, Atmos. Chem. Phys., 10, 8413-8435, doi:10.5194/acp-10-8413-2010, 2010.

Engler, C., Rose, D., Wehner, B., Wiedensohler, A., Brüggemann, E., Gnauk, T., Spindler, G., Tuch, T., and Birmili, W.: Size distributions of non-volatile particle residuals $\left(D_{\mathrm{p}}<800 \mathrm{~nm}\right)$ at a rural site in Germany and relation to air mass origin, Atmos. Chem. Phys., 7, 5785-5802, doi:10.5194/acp-7-5785-2007, 2007.

Gerstengarbe, F.-W. and Werner, P. C.: Katalog der Grosswetterlagen Europas 1881-2004 nach Hess, P. and Brezowsky, H., 6. Aufl., PIK Report, 100, 2005.

Hamed, A., Birmili, W., Joutsensaari, J., Mikkonen, S., Asmi, A., Wehner, B., Spindler, G., Jaatinen, A., Wiedensohler, A., Korhonen, H., Lehtinen, K. E. J., and Laaksonen, A.: Changes in the production rate of secondary aerosol particles in Central Europe in view of decreasing $\mathrm{SO}_{2}$ emissions between 1996 and 2006, Atmos. Chem. Phys., 10, 1071-1091, doi:10.5194/acp-10-10712010, 2010.

Hess, P. and Brezowsky, H.: Katalog der Grosswetterlagen Europas, Berichte des Deutschen Wetterdienstes in der US-Zone, $33,1952$.

Hitzenberger, R. and Tohno, S.: Comparison of black carbon (BC) aerosols in two urban areas - concentrations and size distributions, Atmos. Environ., 35, 2153-2167, 2001.

Holzworth, G. C.: Estimates of mean maximum mixing depths in the contiguous United States, Mon. Weather Rev., 92, 235-242, 1964.

Huang, S., Arimoto, R., and Rahn, K. A.: Sources and source variations for aerosol at Mace Head, Ireland, Atmos. Environ., 35, 1421-1437, 2001.

James, P. M.: An objective classification method for Hess and Brezowsky Grosswetterlagen over Europe, Theor. Appl. Climatol., 88, 17-42, 2007.

Junker, C., Jennings, S. G., and Cachier, H.: Aerosol light absorption in the North Atlantic: trends and seasonal characteristics during the period 1989 to 2003, Atmos. Chem. Phys., 6, 19131925, doi:10.5194/acp-6-1913-2006, 2006.

Kandler, K. and Schütz, L.: Climatology of the average watersoluble volume fraction of atmospheric aerosol, Atmos. Res., 83, 77-92, 2007.

Kukkonen, J., Pohjola, M., Sokhi, R. S., Luhana, L., Kitwiroon, N., Fragkou, L., Rantamäki, M., Berge, E., Ødegaard, V., Slørdal, L. H., Denby, B., and Finardi, S.: Analysis and evaluation of selected local-scale $\mathrm{PM}_{10}$ air pollution episodes in four European cities: Helsinki, London, Milan and Oslo, Atmos. Environ., 39, 2759-2773, 2005.

Kulmala, M., Asmi, A., Lappalainen, H. K., Carslaw, K. S., Pöschl, U., Baltensperger, U., Hov, Ø., Brenquier, J.-L., Pandis, S. N., Facchini, M. C., Hansson, H.-C., Wiedensohler, A., and O'Dowd, C. D.: Introduction: European Integrated Project on Aerosol Cloud Climate and Air Quality interactions (EUCAARI) - integrating aerosol research from nano to global scales, Atmos. Chem. Phys., 9, 2825-2841, doi:10.5194/acp-9-2825-2009, 2009. 
Liu, P. S. K., Leaitch, W. R., Strapp, J. W., and Wasey, M. A.: Response of Particle Measuring Systems Airborne ASASP and PCASP to $\mathrm{NaCl}$ and latex particles, Aerosol Sci. Technol., 16, 83-95, 1992.

McMeeking, G. R., Hamburger, T., Liu, D., Flynn, M., Morgan, W. T., Northway, M., Highwood, E. J., Krejci, R., Allan, J. D., Minikin, A., and Coe, H.: Black carbon measurements in the boundary layer over western and northern Europe, Atmos. Chem. Phys., 10, 9393-9414, doi:10.5194/acp-10-9393-2010, 2010.

Mirme, S., Mirme, A., Minikin, A., Petzold, A., Hõrrak, U., Kerminen, V.-M., and Kulmala, M.: Atmospheric sub-3 nm particles at high altitudes, Atmos. Chem. Phys., 10, 437-451, doi:10.5194/acp-10-437-2010, 2010.

Morgan, W. T., Allan, J. D., Bower, K. N., Highwood, E. J., Liu, D., McMeeking, G. R., Northway, M. J., Williams, P. I., Krejci, R., and Coe, H.: Airborne measurements of the spatial distribution of aerosol chemical composition across Europe and evolution of the organic fraction, Atmos. Chem. Phys., 10, 4065-4083, doi:10.5194/acp-10-4065-2010, 2010.

Müller, K.: A 3 year study of the aerosol in Northwest Saxony (Germany), Atmos. Environ., 33, 1679-1685, 1999.

Niemi, J. V., Saarikoski, S., Aurela, M., Tervahattu, H., Hillamo, R., Westphal, D. L., Aarnio, P., Koskentalo, T., Makkonen, U., Vehkamäki, H., and Kulmala, M.: Long-range transport episodes of fine particles in Southern Finland during 1999-2007, Atmos. Environ., 43, 1255-1264, 2009.

O'Connor, T.-C., Jennings, S. G., and O'Dowd, C.-D.: Highlights of fifty years of atmospheric aerosol research at Mace Head, Atmos. Res., 90, 338-355, 2008.

Pernigotti, D., Rossa, A. M., Ferrario, M. E., Sansone, M., and Benassi, A.: Influence of ABL stability on the diurnal cycle of $\mathrm{PM}_{10}$ concentration: illustration of the potential of the new Veneto network of MW-radiometers and SODAR, Meteorol. Z., 16(7), 505-511, 2007.

Petzold, A. and Schönlinner, M.: Multi-angle absorption photometry - a new method for the measurement of aerosol light absorption and atmospheric black carbon, J. Aerosol Sci., 35, 421-441, 2004.

Pitz, M., Schmid, O., Heinrich, J., Birmili, W., Maguhn, J., Zimmermann, R., Wichmann, H.-E., Peters, A., and Cyrys, J.: Seasonal and Diurnal Variation of $\mathrm{PM}_{2.5}$ Apparent Particle Density in urban air in Augsburg, Germany, Environ. Sci. Technol., 42, 5087-5093, 2008.

Putaud, J.-P., Raes, F., Dingenen, R. V., Brüggemann, E., Facchini, M. C., Decesari, S., Fuzzi, S., Gehrig, R., Hüglin, C., Laj, P., Lorbeer, G., Maenhaut, W., Mihalopoulos, N., Müller, K., Querol, X., Rodriguez, S., Schneider, J., Spindler, G., ten Brink, H., Tørseth, K., and Wiedensohler, A.: A European aerosol phenomenology - 2: chemical characteristics of particulate matter at kerbside, urban, rural and background sites in Europe, Atmos. Environ., 38, 2579-2595, 2004.

Raes, F., Van Dingenen, R., Vignati, E., Wilson, J., Putaud, J.-P., Seinfeld, J. H., and Adams, P.: Formation and cycling of aerosols in the global troposphere, Atmos. Environ., 34, 4215-4240, 2000.

Robles González, C., Schaap, M., de Leeuw, G., Builtjes, P. J. H., and van Loon, M.: Spatial variation of aerosol properties over Europe derived from satellite observations and comparison with model calculations, Atmos. Chem. Phys., 3, 521-533, doi:10.5194/acp-3-521-2003, 2003.
Rose, D., Wehner, B., Ketzel, M., Engler, C., Voigtländer, J., Tuch, T., and Wiedensohler, A.: Atmospheric number size distributions of soot particles and estimation of emission factors, Atmos. Chem. Phys., 6, 1021-1031, doi:10.5194/acp-6-1021-2006, 2006.

Schäfer, K., Emeis, S., Hoffmann, H., and Jahn, C.: Influence of mixing layer height upon air pollution in urban and sub-urban areas, Meteorol. Z., 15(12), 647-658, 2006.

Seibert, P., Beyrich, F., Gryning, S.-E., Joffre, S., Rasmussen, A., and Tercier, P.: Review and intercomparison of operational methods for the determination of the mixing height, Atmos. Environ., 34, 1001-1027, 2000.

Sogacheva, L., Dal Maso, M., Kerminen, V.-M., and Kulmala, M.: Probability of nucleation events and aerosol particle concentration in different air mass types arriving at Hyytiälä, southern Finland, based on back trajectories analysis, Boreal Environ. Res., 10, 479-491, 2005.

Spindler, G., Brüggemann, E., Gnauk, T., Grüner, A., Müller, K., and Herrmann, H.: A four-year size-segregated characterization study of particles $\mathrm{PM}_{10}, \mathrm{PM}_{2.5}$ and $\mathrm{PM}_{1}$ depending on air mass origin at Melpitz, Atmos. Environ., 44, 164-173, 2010.

Stein, C., Schröder, F., and Petzold, A.: The condensation particle size analyzer: a new instrument for the measurement of ultrafine aerosol size distributions, J. Aerosol Sci., 32, 381-382, 2001.

Stephens, M., Turner, N., and Sandberg, J.: Particle identification by laser-induced incandescence in a solid-state laser cavity, Appl. Optics, 42, 3726-3736, 2003.

Stohl, A., Haimberger, L., Scheele, M. P., and Wernli, H.: An intercomparison of results from three trajectory models, Meteorol. Appl., 8, 127-135, 2001.

Stohl, A., Forster, C., Frank, A., Seibert, P., and Wotawa, G.: Technical note: The Lagrangian particle dispersion model FLEXPART version 6.2, Atmos. Chem. Phys., 5, 2461-2474, doi:10.5194/acp-5-2461-2005, 2005.

Tunved, P., Ström, J., and Hansson, H.-C.: An investigation of processes controlling the evolution of the boundary layer aerosol size distribution properties at the Swedish background station Aspvreten, Atmos. Chem. Phys., 4, 2581-2592, doi:10.5194/acp-4-2581-2004, 2004.

Tunved, P., Nilsson, E. D., Hansson, H.-C., Ström, J., Kulmala, M., Aalto, P., and Viisanen, Y.: Aerosol characteristics of air masses in Northern Europe: influences of location, transport, sinks, and sources, J. Geophys. Res., 110, D07201, doi:10.1029/2004JD005085, 2005.

Tyrlis, E. and Hoskins, B. J.: Aspects of a Northern Hemisphere atmospheric blocking climatology, J. Atmos. Sci., 65, 1638-1652, 2008.

Van Dingenen, R., Raes, F., Putaud, J.-P., Baltensperger, U., Charron, A., Facchini, M. C., Decesari, S., Fuzzi, S., Gehrig, R., Hansson, H.-C., Harrison, R. M., Hüglin, C., Jones, A. M., Laj, P., Lorbeer, G., Maenhaut, W., Palmgren, F., Querol, X., Rodriguez, S., Schneider, J., ten Brink, H., Tunved, P., Tørseth, K., Wehner, B., Weingartner, E., Wiedensohler, A., and Wåhlin, P.: A European aerosol phenomenology - 1: physical characteristics of particulate matter at kerbside, urban, rural and background sites in Europe, Atmos. Environ., 38, 2561-2577, 2004.

Vignati, E., de Leeuw, G., Schulz, M., and Plate, E.: Characterization of aerosols at a coastal site near Vindeby (Denmark), J. Geophys. Res., 104, 3277-3287, 1999. 
Wang, S. C. and Flagan, R. C.: Scanning electrical mobility spectrometer, Aerosol Sci. Technol., 13, 230-240, 1990.

Wernli, H. and Davies, H. C.: A lagrangian-based analysis of extratropical cyclones. I: The method and some applications, Q. J. Roy. Meteor. Soc., 123, 467-489, 1997.

Williams, J., de Reus, M., Krejci, R., Fischer, H., and Ström, J.: Application of the variability-size relationship to atmospheric aerosol studies: estimating aerosol lifetimes and ages, Atmos. Chem. Phys., 2, 133-145, doi:10.5194/acp-2-133-2002, 2002.
Yoon, Y. J., Ceburnis, D., Cavalli, F., Jourdan, O., Putaud, J.-P., Facchini, M. C., Decesari, S., Fuzzi, S., Sellegri, K., Jennings, S. G., and O'Dowd, C. D.: Seasonal characteristics of the physicochemical properties of North Atlantic marine atmospheric aerosols, J. Geophys. Res., 112, D04206, doi:10.1029/2005JD007044, 2007. 